\title{
26. PETROLOGY OF VOLCANIC ROCKS DREDGED FROM SEAMOUNTS IN THE LINE ISLANDS
}

\author{
James H. Natland, Scripps Institution of Oceanography, University of California, San Diego La Jolla, California
}

\begin{abstract}
Volcanic rocks dredged from the tops of seamounts in the Line Islands and cored from their flanks demonstrate that this is a region of extreme petrologic diversity. Tholeiitic and alkalic basalts were obtained in a single dredge haul and a wide spectrum of alkalic differentiates, including quartz trachytes, and phonolites were dredged or cored elsewhere. Four dredge stations on widely scattered seamounts recovered potassic nephelinites, unlike any other volcanic rocks heretofore found in the ocean basins. These rocks include amphibole and biotite-bearing varieties, some of which are leucite normative. These lavas are similar to potassic mafic lavas of the western African rifts. They have higher $\mathrm{Al}_{2} \mathrm{O}_{3} / \mathrm{SiO}_{2}$ and $\mathrm{K}_{2} \mathrm{O} / \mathrm{Na}_{2} \mathrm{O}$ ratios than typical posterosional lavas of the Hawaiian or Samoan chains. They contain amphibole-augite or biotite-augite xenoliths similar to inclusions found in the comparable African lavas.

Two tectonic trends dominate the Line Islands chain-a series of north-northwest-trending ridges which define the overall direction of the chain, and a broader belt of west-northwest-trending ridges and troughs most apparent in the bathymetry both west and east of the main Line Islands ridges. This cross-trend persists to the west along the northern portion of the Central Pacific Basin, and may reach as far as the Wake Seamounts, many of which have a west-northwest trend. Potassic mafic lavas similar to those recovered from the Line Islands chain have also been dredged from guyots in the Wake Seamounts. At least two of the Line Islands seamounts from which the potassic nephelinites were dredged are part of the cross-trend; the other two are within the complex zone of intersection of west-northwest- and north-northwest-trending ridges and have no clear orientation. The presence of potassic nephelinites on the Wake and Line seamounts suggests that they are part of a single province structurally linked by the cross-trend. Bathymetric and tectonic evidence suggests that the cross-trend is an 85-105 m.y. old Central Pacific rift system that experienced only limited crustal extension. The presence of these rocks supports this interpretation since potassic nephelinites have been found elsewhere only in regions of slow tensional tectonics, such as the rifts of East Africa. Volcanism within the crosstrend appears to have been mainly alkalic. It was not confined to a single spreading "center," but instead occurred along a mosaic of crustal fissures. At DSDP Sites 165 and 170, alkalic lavas erupted directly onto the sea floor.

The north end of the main north-northwest Line Islands ridges is as old as $128 \mathrm{~m} . \mathrm{y}$. (by ${ }^{40} \mathrm{Ar} /{ }^{39} \mathrm{Ar}$ techniques) where trachytes and phonolites have been dredged in two places. The age of the northnorthwest ridges further south is unknown and confused by the intersection with the cross-trend. Data are insufficient to distinguish the main ridges from the cross-trend petrologically, apart from the potassic nephelinites which are probably restricted to the crosstrend. Critical parameters such as $\mathrm{Na}_{2} \mathrm{O}+\mathrm{K}_{2} \mathrm{O}$ vs $\mathrm{SiO}_{2}$, normative $\mathrm{Ne}$, and $\mathrm{K} / \mathrm{Rb}$ indicate that mildly alkalic to strongly alkalic differentiates developed on both the main ridges and the cross-trend, and that amphibole and phlogopite may have been important minor phases in the mantle source regions of parental lavas for both sets of volcanic ridges.
\end{abstract}

\section{INTRODUCTION}

This chapter presents petrographic descriptions and chemical analyses of rocks dredged from the tops of seamounts in the Line Islands on SIO's Expedition 7 TOW,
Leg 6. Volcanic rocks cored on DSDP Legs 17 and 33 in the Line Islands and the Central Pacific Basin (Bass et al., 1973; Jackson, this volume) are also discussed, in addition to rocks dredged and cored in the Mid-Pacific Mountains and the Wake Seamounts (Winterer, Ewing, 
et al., 1973; Natland, 1974) which flank the Central Basin. Though the rocks represent extremely thin coverage of a vast area of the Pacific, several samples are of such an unusual nature that they corroborate bathymetric and stratigraphic/radiometric age evidence that an episode of anomalous, slow extensional tectonics and volcanism occurred in the Central Pacific 85-105 m.y. ago.

The region affected stretches from east of the main Line Islands ridges, which trend north-northwest, across the northern part of the Central Pacific Basin at least as far as the vicinity of Wake Island, and perhaps even further to the west (Figure 1). The primary expression of the extensional zone is a series of west-northwesttrending ridges which cross obliquely through the main Line Islands ridges (and are henceforth called the Line Islands cross-trend, or simply the cross-trend). Many major volcanoes aligned west-northwest define a belt up to $5^{\circ}$ in width, especially in the vicinity of the Line Islands. The west-northwest relief is more subdued through the Central Basin, and apparently, though less certainly, major west-northwest-trending bathymetry occurs in the Wake Seamount province. The main features of this trend and its intersection with the Line Islands chain are presented by Winterer (this volume). Pertinent to the present discussion are (1) younger basement ages in DSDP cores within this region than the Phoenix magnetic lineations to the south and the Hawaiian lineations to the north, both of which become younger away from the cross-trend region; (2) a regional topographic high within and along the length of the cross-trend; (3) ridge and trough topography arrayed west-northwest along the cross-trend with no known fracture zone offsets perpendicular to the trend; (4) intersection of the cross-trend with and propagation through the north-northwest Line Islands ridges, which appear to be older than the cross-trend, at least at the northern end (see Ozima and Saito, 1974; Winterer, this volume); (5) paleontologic and stratigraphic evidence that the ridges of the Line Islands chain were uplifted 85-90 m.y. ago, for the first time above sea level, at which time reefs first became established (Jackson and Schlanger, this volume). These relations point to regional extension which produced ridges that cut through older crust in the Central Basin and older ridges in the Line Islands chain (Lanphere and Dalrymple, this volume). The extensional zone did not become a fullfledged spreading center, at least in the region of the Line Islands chain. The ridge-trough topography and lack of fracture zones are consistent with relatively minor crustal thinning rather than sea-floor spreading.

Two aspects of the petrology of volcanic rocks from the cross-trend support slow, relatively minor extensional tectonics: (1) Volcanism along the cross-trend was principally alkalic to strongly alkalic. A wide spectrum of felsic differentiates erupted not only at the tops of seamounts, but directly onto the sea floor at relatively great distances from large volcanoes (e.g., DSDP Sites 165 and 170, Bass et al., 1973). The compositions of these rocks are unlike basalt compositions even from slow spreading ridges. (2) At six locations, four within or near the Line Islands chain at the eastern end of the cross-trend and two within the Wake Seamounts to the west, potassic nephelinites and related rocks have been dredged. Such rocks have not previously been recovered from the ocean basins and are unlike those of the final, posterosional stages of volcanism on oceanic islands, which tend to be sodic basanites and nephelinites. The cross-trend potassic nephelinites resemble potassic mafic lavas of the Toro-Ankole region of the western African rift system. The general association of such lavas with regions of slow extensional crustal rifting and not with oceanic islands suggests a rift-type tectonic association for the cross-trend rocks as well. The lack of potassic nephelinites on oceanic islands underscores the peculiarity of dredging them from two widely separated regions along the cross-trend. These rocks indicate that the Wake and Line seamounts from which they were dredged are part of a single petrologic province, structurally linked by the cross-trend. Available age data, though limited, suggest that the Wake and Line seamounts may be approximately contemporaneous.

All other alkalic lavas dredged in the Line Islands chain are similar to alkalic rocks from islands and seamounts in the sense of having higher $\mathrm{Na}_{2} \mathrm{O}$ and $\mathrm{K}_{2} \mathrm{O}$. One dredge haul from the northern end of the northnorthwest set of Line Islands ridges recovered trachytes. Another recovered phonolites. One dredge haul from the cross-trend contains hawaiite and altered mugearite. None of the other dredged seamounts can definitely be assigned to either set of ridges. Discounting the potassic nephelinites, the petrology of the chain still appears exceptionally diverse. A wide variety of felsic differentiates have been dredged, and it can be shown that virtually none of the lavas shares a common magmatic lineage. Chemical characteristics inherited by the differentiated lavas appear to reflect different parental compositions, different mineralogical sequences and controls during fractionation, probable source heterogeneities, and different depths of melting of parental lavas within the mantle.

\section{DREDGE LOCATIONS AND FIELD RELATIONS: THE FORMATION OF SUBMARINE VOLCANIC BRECCIAS}

Most of the dredged materials have characteristics in common which reveal a general pattern of eruption, transport, deposition, and diagenesis of submarine lavas. Table 1 lists the dredge stations, localities, type of structure, mode of extrusion, and major lithologies dredged (see also Figure 1 and Plate 1). In every case, an effort was made to dredge at or near the tops of the seamounts and ridges; in the case of guyots, hauls were made across the main break in slope. No coral or shallow-water fossils were recovered, even on guyots, and no stream or beach-produced sands were dredged. Most of the dredge hauls contained thickly manganese-oxideencrusted hyaloclastites (fragmental, quenched volcanic glass) intensely altered to palagonite. Lithic volcanic fragments (from 10 to $50 \mathrm{~cm}$ in diameter) were either embedded in these breccias or formed separate manganese-encrusted boulders (Plate 5, Figures 4-8). Foraminifer oozes embedded in cracks and cavities in the breccias were usually replaced by phosphorite (Plate 5, Figures 6-8). In most cases, it was possible to apply 


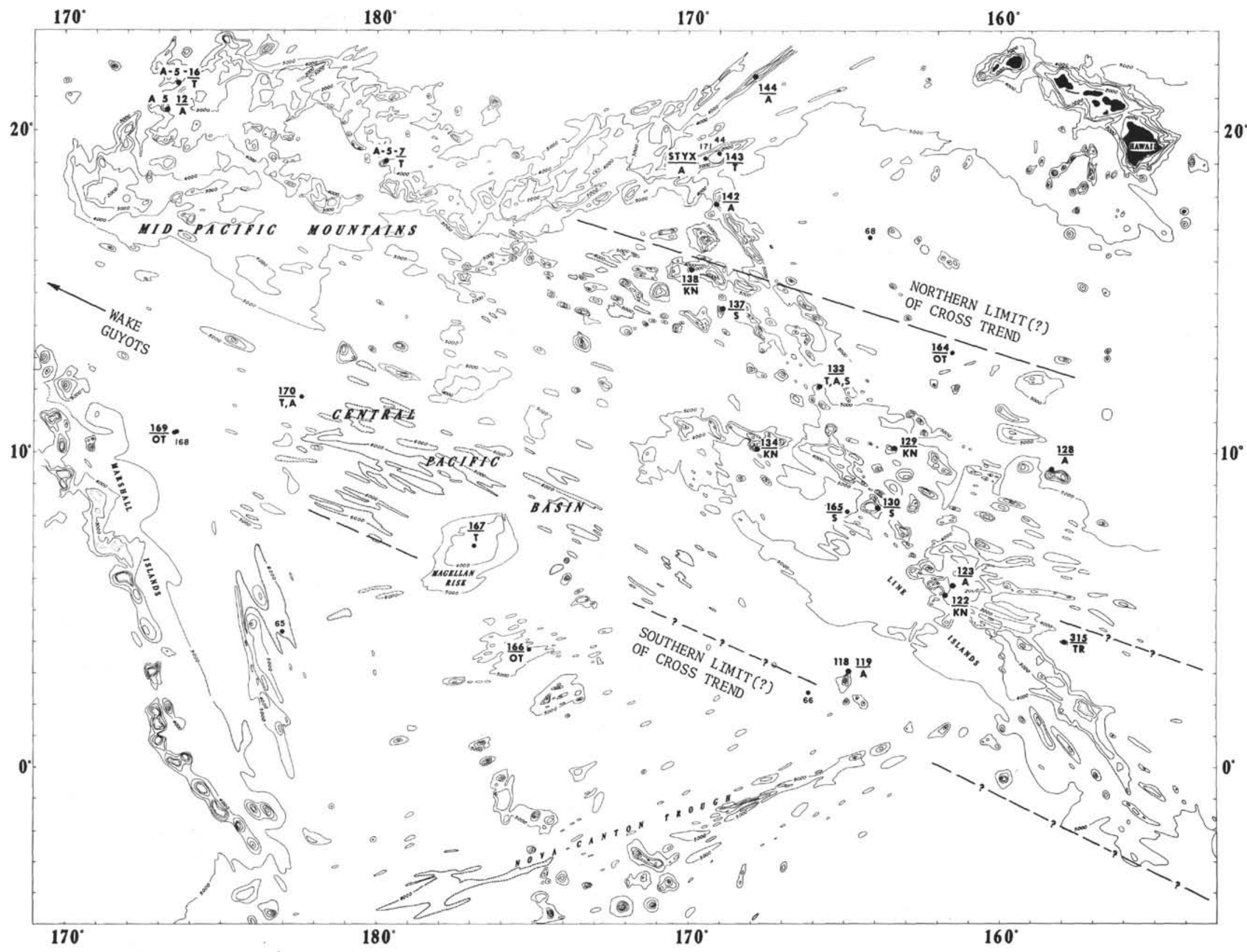

Figure 1. Central Basin of the Pacific (from Winterer, Ewing, et al., 1973). 7 TOW Leg 6, Aries Leg 5, and DSDP drill sites are indicated. Lavas from these sites are labeled. $O T=$ oceanic tholeiitic basalts; $T R=$ island edifice transitional basalts; $A=$ alkalic series lavas (alkalic basalt, hawaiite, mugearite, or trachyte); $S=$ strongly alkalic series lavas (basanite, nephelinite, trachyandesite, phonolite); $K N=$ potassic nephelinite. 
TABLE 1

Line Islands Chain

\begin{tabular}{|c|c|c|c|}
\hline Dredge & Major Lithologies & Mode of Extrusion & Locality \\
\hline 7 TOW 6-118-D & $\begin{array}{l}\text { Hawaiite } \\
\text { Hyaloclastites } \\
\text { Phosphorite and } \\
\text { limestone } \\
\text { Manganese oxides }\end{array}$ & $\begin{array}{l}\text { Aquagene tuff; } \\
\text { broken pillow } \\
\text { breccia }\end{array}$ & $\begin{array}{l}\text { Seamount at } \\
2^{\circ} 45^{\prime} \mathrm{N}, \\
165^{\circ} 01^{\prime} \mathrm{W}\end{array}$ \\
\hline 7 TOW 6-119-D & $\begin{array}{l}\text { Mugearite }(119-1)^{\mathrm{a}} \\
\text { Hyaloclastites } \\
\text { Phosphoite and } \\
\text { limestone } \\
\text { Manganese oxides }\end{array}$ & $\begin{array}{l}\text { Flow } \\
\text { Aquagene tuff; } \\
\text { broken pillow } \\
\text { breccia }\end{array}$ & $\begin{array}{l}\text { Seamount at } \\
2^{\circ} 45^{\prime} \mathrm{N} \\
165^{\circ} 01 \mathrm{~W}\end{array}$ \\
\hline 7 TOW 6-122-D & $\begin{array}{l}\text { Potassic nephelinite (122-1) } \\
\text { Hyaloclastites } \\
\text { Phosphorite and } \\
\text { limestone } \\
\text { Manganese oxides }\end{array}$ & $\begin{array}{l}\text { Aquagene tuff; } \\
\text { broken pillow } \\
\text { breccia }\end{array}$ & $\begin{array}{l}\text { Flat-topped } \\
\text { ridge trending } \\
\text { WNW at } \\
5^{\circ} 14^{\prime} \mathrm{N} \\
161^{\circ} 30^{\prime} \mathrm{W}\end{array}$ \\
\hline 7 TOW 6-123-D & $\begin{array}{l}\text { Alkalic basalt (123-15) } \\
\text { Hyaloclastites } \\
\text { Phosphorite and } \\
\text { limestone } \\
\text { Manganese oxides }\end{array}$ & $\begin{array}{l}\text { Aquagene tuff; } \\
\text { broken pillow } \\
\text { breccia }\end{array}$ & $\begin{array}{l}\text { Flat-topped } \\
\text { ridge trending } \\
\mathrm{NNW} \text { at } \\
5^{\circ} 50^{\prime} \mathrm{N} \\
160^{\circ} 45^{\prime} \mathrm{W}\end{array}$ \\
\hline 7 TOW 6-128-D & $\begin{array}{l}\text { Mugearite } \\
\text { Hawaiite (128-1) } \\
\text { Hyaloclastites } \\
\text { Manganese oxides } \\
\text { Minor foraminiferal ooze }\end{array}$ & $\begin{array}{l}\text { Aquagene tuff; } \\
\text { isolated pillow } \\
\text { breccia }\end{array}$ & $\begin{array}{l}\text { Twin guyot } \\
\text { trending WNW } \\
\text { at } 9^{\circ} 15^{\prime} \mathrm{N} \text {, } \\
160^{\circ} 45^{\prime} \mathrm{W}\end{array}$ \\
\hline 7 TOW 6-129-D & $\begin{array}{l}\text { Potassic nephelinite (129-2) } \\
\text { Hyaloclastites } \\
\text { Phosphorite and } \\
\text { limestone } \\
\text { Manganese oxides }\end{array}$ & $\begin{array}{l}\text { Aquagene tuff; } \\
\text { broken pillow }\end{array}$ & $\begin{array}{l}\text { Seamount (pos- } \\
\text { sible collapse } \\
\text { feature) at } \\
9^{\circ} 20^{\prime} \mathrm{N} \text {, } \\
163^{\circ} 10^{\prime} \mathrm{W}\end{array}$ \\
\hline 7 TOW 6-130-D & $\begin{array}{l}\text { Olivine-poor alkalic basalt } \\
\text { (basanatoid) }(130-2) \\
\text { Hyaloclastites } \\
\text { Phosphorite and } \\
\text { limestone } \\
\text { Manganese oxides }\end{array}$ & $\begin{array}{l}\text { Aquagene tuff; } \\
\text { broken pillow } \\
\text { breccia }\end{array}$ & $\begin{array}{l}\text { Guyot at } \\
8^{\circ} 20^{\prime} \mathrm{N}, \\
164^{\circ} 22^{\prime} \mathrm{W}\end{array}$ \\
\hline 7 TOW 6-133-D & $\begin{array}{l}\text { Tholeiitic basalt (133-21) } \\
\text { Picritic alkali basalt } \\
\text { Hawaiite (133-9, 133-22, } \\
\text { 133-23) } \\
\text { Mugearite } \\
\text { Benmorite } \\
\text { Phosphorite and } \\
\text { limestone } \\
\text { Phosphorite cemented } \\
\text { volcanic sandstones } \\
\text { Minor hyaloclastites } \\
\text { Manganese oxides }\end{array}$ & $\begin{array}{l}\text { Probably aquagene } \\
\text { tuffs, but may } \\
\text { include pyro- } \\
\text { clastic material }\end{array}$ & $\begin{array}{l}\text { Seamount at } \\
12^{\circ} 04^{\prime} \mathrm{N} \\
165^{\circ} 50^{\prime} \mathrm{W}\end{array}$ \\
\hline 7 TOW 6-134-D & $\begin{array}{l}\text { Biotite-bearing potassic } \\
\text { nephelinite } \\
\text { Hyaloclastites (134-1) } \\
\text { Phosphorite and } \\
\text { limestone (134-N) }\end{array}$ & $\begin{array}{l}\text { Aquagene tuff; } \\
\text { broken pillow } \\
\text { breccia }\end{array}$ & $\begin{array}{l}\text { Seamount on } \\
\text { WNW trend; } \\
10^{\circ} 18^{\prime} \mathrm{N} \text {, } \\
168^{\circ} 00^{\prime} \mathrm{W}\end{array}$ \\
\hline 7 TOW 6-137-D & $\begin{array}{l}\text { Phonolite (137-1, } \\
\text { 137-11) } \\
\text { Hyaloclastites } \\
\text { Phosphorite and } \\
\text { limestone } \\
\text { Phosphorite cemented } \\
\text { trachyte conglomerates } \\
\text { Manganese oxides }\end{array}$ & $\begin{array}{l}\text { Fluidized pyro- } \\
\text { clastic breccia }\end{array}$ & $\begin{array}{l}\text { Seamount } \\
\text { on NNW trend; } \\
14^{\circ} 27^{\prime} \mathrm{N} \text {, } \\
168^{\circ} 59^{\prime} \mathrm{W}\end{array}$ \\
\hline 7 TOW 6-138-D & $\begin{array}{l}\text { Potassic nephelinite } \\
\text { Hyaloclastite } \\
\text { Minor phosphorite } \\
\text { Manganese oxides }\end{array}$ & $\begin{array}{l}\text { Aquagene tuff; } \\
\text { broken pillow } \\
\text { breccia }\end{array}$ & $\begin{array}{l}\text { Ridge trending } \\
\text { WNW at } \\
15^{\circ} 39^{\prime} \mathrm{N}, \\
169^{\circ} 18^{\prime} \mathrm{W}\end{array}$ \\
\hline
\end{tabular}


TABLE 1 - Continued

\begin{tabular}{|c|c|c|c|}
\hline Dredge & Major Lithologies & Mode of Extrusion & Locality \\
\hline 7 TOW 6-142-D & $\begin{array}{l}\text { Trachyte }(142-1) \\
\text { Phosphorite cemented } \\
\text { trachyte conglomerates } \\
\text { and sandstones } \\
\text { Minor limestone } \\
\text { Manganese oxides }\end{array}$ & Probably flow & $\begin{array}{l}\text { Ridge trending } \\
\text { NNW at } \\
18^{\circ} 00^{\prime} \mathrm{N} \\
169^{\circ} 05^{\prime} \mathrm{W}\end{array}$ \\
\hline \multicolumn{4}{|c|}{ Wake Guyots } \\
\hline $\begin{array}{l}\text { Aries } 5-19 \\
\quad \text { (Wilde Guyot) }\end{array}$ & $\begin{array}{l}\text { Rounded trachyte cobble } \\
\text { in chalk } \\
\text { Hyaloclastites }\end{array}$ & Unknown & $\begin{array}{l}21^{\circ} 09.0^{\prime} \mathrm{N} \\
163^{\circ} 22.0^{\prime} \mathrm{E}\end{array}$ \\
\hline Aries 5-25 & $\begin{array}{l}\text { Potassic nephelinite } \\
\text { (A-5-25-1) } \\
\text { Hyaloclastites } \\
\text { Phosphatic mudstones }\end{array}$ & $\begin{array}{l}\text { Aquagene tuff; } \\
\text { isolated pillow } \\
\text { breccia }\end{array}$ & $\begin{array}{l}23^{\circ} 42.2^{\prime} \mathrm{N} \\
159^{\circ} 32.8^{\prime} \mathrm{E}\end{array}$ \\
\hline \multicolumn{4}{|c|}{ Mid-Pacific Mountains } \\
\hline $\begin{array}{l}7 \text { TOW 6-144-D } \\
\text { (Necker Ridge) }\end{array}$ & $\begin{array}{l}\text { Olivine theralite (144-2) } \\
\text { Alkalic olivine basalt } \\
\text { Barite-rich mud } \\
\text { Manganese oxides } \\
\text { Minor limestone }\end{array}$ & Flow material & $\begin{array}{l}\text { ENE-trending } \\
\text { ridge at } \\
21^{\circ} 32^{\prime} \mathrm{N}, \\
167^{\circ} 56^{\prime} \mathrm{E}\end{array}$ \\
\hline MP $25-2-\mathrm{F}$ & $\begin{array}{l}\text { Alkalic olivine basalt } \\
\text { (MP-25-2-F-1) } \\
\text { Hyaloclastites cemented } \\
\text { with phorphorite } \\
\text { Manganese crusts }\end{array}$ & Aquagene tuff & $\begin{array}{l}19^{\circ} 07^{\prime} \mathrm{N} \\
169^{\circ} 44 \mathrm{~W}\end{array}$ \\
\hline
\end{tabular}

${ }^{a}$ Analyzed samples are numbered in parentheses.

the terminology of Carlisle (1963) to the subaqueous extrusives, which he termed aquagene tuffs. Using Carlisle's terminology, hyaloclastites with no recognizable pillow lava fragments are here termed broken pillow breccias (Table 1; Figure 2). Where identifiable pillow fragments were dredged, the hyaloclastites are termed isolated pillow breccias. These relationships are shown schematically in Figure 2. Carlisle (1963) described a process of submarine extrusion in which lava disintegrates upon contact with sea water by contracting, cracking, and breaking into small (less than $1 \mathrm{~cm}$ ) angular fragments. Expanding steam in the developing cracks probably is the major cause of this fragmentation (Bonatti, 1965). The breccias appear to build as an ever-thickening carapace on advancing flows, which repeatedly override and intrude their own surficial debris as they move downslope. The longer the flow continues to move, the thicker the carapace becomes. The breccia fragments abrade and round each other and eventually become embedded in their own crushed glass matrix. Pillow-shaped lobes of lava intrude the breccia mass from the flow below and are broken off and themselves abraded by differential movements within the breccia flow unit, probably even before they begin to cool. They thus usually lose the more fragile, chilled glass rinds usually found on pillows. Once the flow ceases moving, slumping and mixing with foraminifer sands produces talus, probably chiefly at the end of the flow. Alteration to palagonite ensues, leaving relatively fresh but extremely irregular or angular volcanic flow fragments embedded in an orange or red al- tered glass matrix. Dragging a dredge across the surface of such a mass thus tends to recover only the most abraded and fragmental materials, or very commonly, the dredge recovers chiefly talus.

Aquagene tuffs were dredged from three guyots and two flat-topped ridges in the Line Islands chain (see Table 1). The absence of shallow-water fossils and beach sands or stream gravels in dredges across the main breaks in slope of these features indicates either that volcanism postdated erosional truncation and/or reef drowning and buried these materials, or that the volcanoes never were above sea level (Natland et al., 1972; this volume, Chapter 27).

Line Islands seamounts appear to be surrounded by a considerable amount of debris slumped from their flanks, as demonstrated by volcaniclastic sediments cored in DSDP sites on Legs 17 and 33 (see Kelts and McKenzie, this volume). The volcanics dredged from the tops of Line Islands seamounts are not turbiditycurrent deposits (which should be more abundant downslope) with one possible exception. A finely laminated rock dredged at station 133-D is composed of welded palagonitized glass fragments of very uniform size about $0.02 \mathrm{~mm}$. It contains no crystals, demonstrating that sorting was extremely efficient, and has a few very lowangle cross-laminations.

A true submarine ignimbrite was dredged at station 137-D. Virtually the entire dredge haul was composed of manganese-encrusted boulders of green phonolite. Several of the larger boulders consist of generally angular but sometimes rounded cobbles of green phonolite 


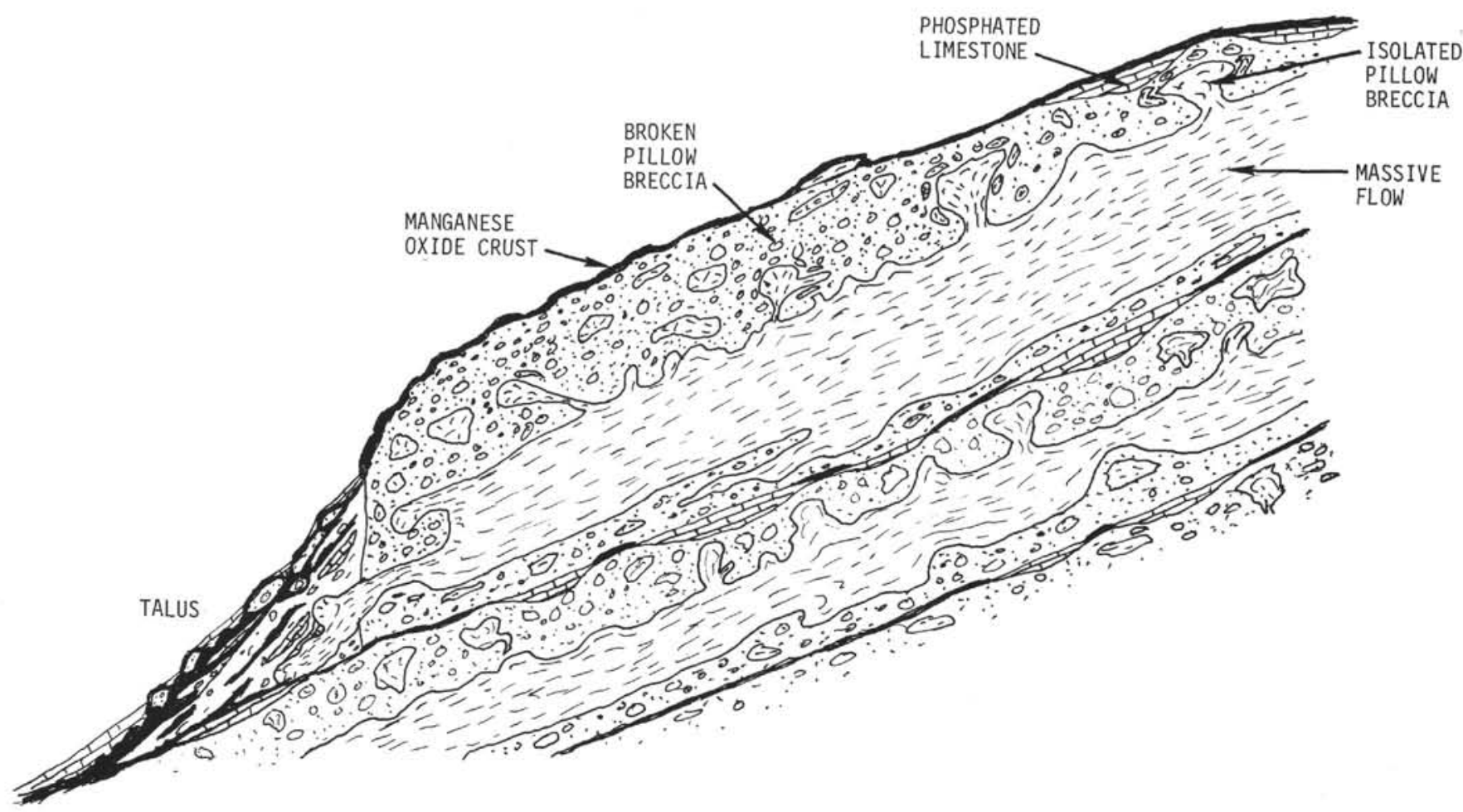

Figure 2. Diagrammatic cross-section of a series of aquagene tuffs and flows, patterned after descriptions of Carlisle (1963) and materials dredged on SIO Expedition 7 TOW Leg 6.

(10-20 $\mathrm{cm}$ in diameter) embedded in a very fine, friable, cream-colored matrix of glass shards and lapilli, no larger than $1 \mathrm{~mm}$, now altered to clays and zeolites. The phonolite cobbles are variably altered from cobble to cobble, but the alteration has no apparent relationship to the matrix. This indicates that alteration of the phonolite fragments occurred elsewhere and that they were entrained in their present matrix during its eruption. The essential contrast between this breccia and the hyaloclastites described earlier is that the matrix surrounding the phonolite clasts is uniformly very fine grained and has no angular, palagonitized glass fragments. The matrix is reminiscent of fine-grained subaerial welded tuffs.

All rocks dredged in the Line Islands are thickly encrusted with manganese oxides. Usually, nodules and boulders of volcanic flow material or hyaloclastites are completely surrounded by the crusts, demonstrating their continued tendency to break off original outcrops long after eruption.

Hyaloclastites completely cemented by phosphorite, which replaces original foraminiferal sediments, are found in several dredge hauls. Mixing of pelagic sediments and glass fragments apparently can be extremely efficient, since the volcanic shards are commonly found to be well sorted and evenly distributed in their phosphorite matrix. All evidence indicates that formation of palagonite, phosphorite, and manganese crusts occurs after all processes of eruption, transport, and deposition of the breccia flow units and after most subsequent erosion and mixing with planktonic sediments. The development of manganese crusts appears finally to cement these extremely fragmental materials in place and inhibit their movement downslope.

\section{CHEMICAL ANALYSES AND PETROGRAPHY OF ROCKS DREDGED FROM THE LINE ISLANDS AND VICINITY}

\section{Chemical Analyses}

Analyses for this report were done by X-ray fluorescence and atomic absorption techniques (for details see Clague, 1974). Samples were dried at $110^{\circ}$ prior to preparation of pellets and solutions. The analyses presented in Tables 2 and 3 should therefore be considered free of uncombined water $\left(\mathrm{H}_{2} \mathrm{O}^{-}\right)$. The totals of the analyses are all below $100 \%$; a few are considerably below. Neither combined water $\left(\mathrm{H}_{2} \mathrm{O}^{+}\right)$nor the proportion of iron as $\mathrm{Fe}_{2} \mathrm{O}_{3}$ was determined. The difference between the given analyses and $100 \%$ is therefore chiefly a measure of the extent of alteration of the rocks, with the exception of those rocks that contain primary amphibole or mica. For rocks free of hydrous magmatic minerals, totals of $97 \%$ or greater indicate that they are relatively fresh. Totals between $94 \%$ and $97 \%$ indicate a moderate degree of alteration, and that the original composition of the rocks may have been modified. In most cases, alteration is primarily replacement of olivine by clays and hydrous iron oxides. $\mathrm{MgO}$, $\mathrm{Ni}$, and $\mathrm{Cr}$ (Table 4) are probably lower in the altered rocks than initially, and $\mathrm{FeO}^{*}$ has also been modified, but to a less certain extent. Alkalis, $\mathrm{TiO}_{2}, \mathrm{Zr}$, and $\mathrm{Rb}$ (Table 4), which are critical in distinguishing alkalic from tholeiitic series lavas, are probably intact. Rocks whose analyses total less than $94 \%$ show visible alteration of feldspars, pyroxenes, and/or intersertal glass, and their chemical composition can only be used to characterize the rocks in a general way. Rocks with abundant hydrous magmatic minerals may initially have 
TABLE 2

Nephelinites and Potassic Nephelinites from Line Islands Seamounts and Wake Seamounts

\begin{tabular}{|c|c|c|c|c|c|c|c|c|c|c|}
\hline \multirow[b]{2}{*}{$\mathrm{SiO}_{2}$} & \multicolumn{2}{|c|}{$122-1$} & \multicolumn{2}{|c|}{$129-2$} & \multicolumn{2}{|c|}{$134-1$} & \multicolumn{2}{|c|}{$134-\mathrm{N}$} & \multicolumn{2}{|c|}{ A-5-25-1 } \\
\hline & 33.50 & 36.14 & 38.00 & 41.20 & 37.60 & 43.14 & 40.10 & 41.20 & 45.00 & 48.58 \\
\hline $\mathrm{TiO}_{2}^{2}$ & 3.58 & 3.86 & 3.96 & 4.29 & 4.02 & 4.62 & 4.91 & 5.05 & 2.71 & 2.92 \\
\hline $\mathrm{Al}_{2} \mathrm{O}_{3}$ & 13.85 & 14.94 & 14.33 & 15.54 & 11.35 & 13.03 & 9.95 & 10.23 & 15.90 & 17.17 \\
\hline $\mathrm{FeO}^{*}$ & 12.50 & 13.48 & 11.22 & 12.16 & 11.76 & 13.50 & 11.69 & 12.02 & 9.60 & 10.36 \\
\hline $\mathrm{MnO}$ & 0.18 & 0.19 & 0.19 & 0.21 & 0.17 & & 0.11 & & 0.17 & 0.18 \\
\hline $\mathrm{MgO}$ & 3.89 & 4.20 & 5.17 & 5.60 & 5.59 & 6.42 & 9.66 & 9.93 & 3.91 & 4.22 \\
\hline $\mathrm{CaO}$ & 16.08 & 17.35 & 13.27 & 14.39 & 10.75 & 12.34 & 14.56 & 14.97 & 9.97 & 10.76 \\
\hline $\mathrm{Na}_{2} \mathrm{O}$ & 2.20 & 2.37 & 1.43 & 1.55 & 1.95 & 2.24 & 0.92 & 0.95 & 1.80 & 1.94 \\
\hline $\mathrm{K}_{2} \mathrm{O}$ & 1.58 & 1.70 & 1.25 & 1.36 & 2.05 & 2.35 & 2.94 & 3.02 & 2.67 & 2.88 \\
\hline $\mathrm{P}_{2} \mathrm{O}_{5}$ & 5.34 & 5.76 & 3.33 & 3.61 & 1.81 & 2.08 & 2.36 & 2.43 & 0.88 & 0.95 \\
\hline $\mathrm{NiO}$ & & & 0.02 & 0.02 & 0.02 & 0.02 & 0.02 & 0.02 & 0.01 & 0.01 \\
\hline $\mathrm{Cr}_{2} \mathrm{O}_{3}$ & & & 0.07 & 0.08 & 0.07 & 0.08 & 0.05 & 0.05 & 0.02 & 0.02 \\
\hline & 92.70 & 99.99 & 92.24 & 100.01 & 87.08 & 100.02 & 97.27 & 99.98 & 92.64 & 99.99 \\
\hline
\end{tabular}

Niggli Molecular Norms

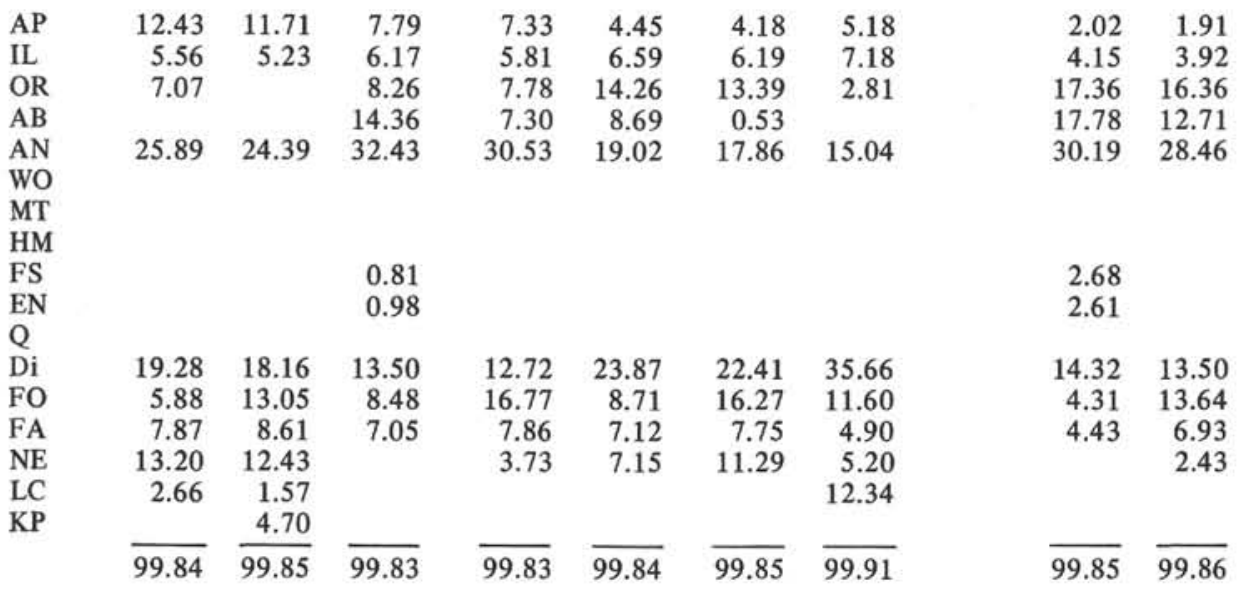

Potassic Mafic Lavas from East Africa and Australia With Similarities to Line Seamounts Potassic Nephelinites

\begin{tabular}{|c|c|c|c|c|c|}
\hline & $1^{a}$ & $2^{b}$ & $3^{c}$ & $4^{d}$ & $5^{\mathrm{e}}$ \\
\hline $\mathrm{SiO}_{2}$ & 33.48 & 36.71 & 43.06 & 46.78 & 48.51 \\
\hline $\mathrm{TiO}_{2}$ & 4.53 & 5.54 & 3.60 & 2.47 & 2.92 \\
\hline $\mathrm{Al}_{2} \mathrm{O}_{3}$ & 12.12 & 9.30 & 13.06 & 13.24 & 15.83 \\
\hline $\mathrm{Fe}_{2} \mathrm{O}_{3}$ & 8.20 & 9.44 & 4.68 & 2.64 & 2.01 \\
\hline $\mathrm{FeO}$ & 3.89 & 4.24 & 8.10 & 7.85 & 8.56 \\
\hline $\mathrm{MnO}$ & 0.24 & 0.26 & 0.43 & 0.18 & 0.19 \\
\hline $\mathrm{MgO}$ & 5.84 & 6.34 & 9.92 & 11.64 & 5.56 \\
\hline $\mathrm{CaO}$ & 14.69 & 14.08 & 9.30 & 8.59 & 8.41 \\
\hline $\mathrm{Na}_{2} \mathrm{O}$ & 2.62 & 2.40 & 2.14 & 2.20 & 2.1 \\
\hline $\mathrm{K}_{2} \mathrm{O}$ & 4.04 & 6.05 & 2.14 & 2.72 & 4.19 \\
\hline $\mathrm{P}_{2} \mathrm{O}_{5}$ & 1.11 & 1.11 & 0.96 & 0.55 & 0.57 \\
\hline $\mathrm{H}_{2} \mathrm{O}-$ & 2.86 & 1.82 & 0.55 & 0.57 & 0.75 \\
\hline $\mathrm{H}_{2} \mathrm{O}+$ & 2.48 & 0.42 & 0.57 & 0.26 & 0.26 \\
\hline $\mathrm{CO}_{2}$ & 3.02 & 1.30 & & 0.03 & 0.01 \\
\hline \multirow[t]{2}{*}{$\begin{array}{l}\text { Trace } \\
\text { elements }\end{array}$} & 0.48 & 0.59 & & 0.69 & 0.52 \\
\hline & 0.11 & 99.60 & 00.68 & 100.23 & 00.2 \\
\hline
\end{tabular}

Note: For Table 2; column 1 for each analysis has norm calculated reduced. Column 2 has $4 \% \mathrm{MgO}$ added to the analysis to make up for lost $\mathrm{MgO}$ in altered olivines, except for 134-N.

${ }^{a}$ Melaleacitite, S. W. Uganda Katwe Kikorongo Volcanic Field; analyst, W. H. Herdsman Holmes (1952) Table 7 \#C4.

${ }^{b}$ Phlogopite-bearing potash ankaratrite, Carmichael et al. (1974) n. 256 Table 5-3 \#2 from Brown (1971).

${ }^{c_{L i m b u r g i t e}}$ (Murambitoid) Macedon District, Victoria Geol. Surv. Vict. Bull 24, 1912, p. 28 \#II; analyst, A. G. Hall.

d Murambite, Murambe Volcano, Bufambira, analysis C 2803, Holmes and Harwood.

' Shoshonitic Absarokite; Mgahiuga, Bufumbira analysis C 1894, Holmes and Harwood. 
TABLE 3

Basalts and Felsic Differentiates, Line Islands Seamounts

\begin{tabular}{|c|c|c|c|c|c|c|c|c|c|c|c|c|c|c|}
\hline \multirow[b]{2}{*}{$\mathrm{SiO}_{2}$} & \multicolumn{2}{|c|}{$119-1$} & \multicolumn{2}{|c|}{$123-15$} & \multicolumn{2}{|c|}{$128-1$} & \multicolumn{2}{|c|}{$130-2$} & \multicolumn{2}{|c|}{$133-9$} & \multicolumn{2}{|c|}{$133-21$} & \multicolumn{2}{|c|}{$133-22$} \\
\hline & 53.20 & 54.55 & 43.30 & 44.81 & 47.00 & 49.67 & 41.20 & 43.23 & 44.60 & 47.68 & 49.60 & 51.02 & 47.70 & 48.64 \\
\hline $\mathrm{TiO}_{2}$ & 1.91 & 1.96 & 3.96 & 4.09 & 3.34 & 3.53 & 4.97 & 5.22 & 4.33 & 4.62 & 2.00 & 2.06 & 2.06 & 3.85 \\
\hline $\mathrm{Al}_{2} \mathrm{O}_{3}$ & 17.74 & 18.19 & 14.16 & 14.64 & 14.82 & 15.66 & 14.37 & 15.09 & 16.02 & 17.11 & 14.52 & 14.50 & 17.90 & 18.24 \\
\hline $\mathrm{FeO}^{*}$ & 5.94 & 6.09 & 13.36 & 13.81 & 12.94 & 13.67 & 13.13 & 13.79 & 12.02 & 12.84 & 9.90 & 10.19 & 11.93 & 12.17 \\
\hline $\mathrm{MnO}$ & 0.11 & 0.11 & 0.25 & 0.26 & 0.21 & 0.22 & 0.17 & 0.18 & 0.19 & 0.20 & 0.31 & 0.32 & 0.25 & 0.26 \\
\hline $\mathrm{MgO}$ & 0.80 & 0.82 & 6.16 & 6.37 & 3.11 & 3.29 & 5.86 & 6.15 & 2.63 & 2.81 & 5.41 & 5.57 & 2.00 & 2.04 \\
\hline $\mathrm{CaO}$ & 7.84 & 8.03 & 10.52 & 10.88 & 7.81 & 8.25 & 10.83 & 11.37 & 6.56 & 7.00 & 10.87 & 11.19 & 6.61 & 6.74 \\
\hline $\mathrm{Na}_{2} \mathrm{O}$ & 6.18 & 6.34 & 2.35 & 2.43 & 3.55 & 3.75 & 2.75 & 2.88 & 3.65 & 3.90 & 3.42 & 3.52 & 4.32 & 4.41 \\
\hline $\mathrm{K}_{2} \mathrm{O}$ & 1.88 & 1.93 & 1.75 & 1.81 & 0.88 & 0.93 & 1.46 & 1.53 & 2.28 & 2.44 & 0.44 & 0.45 & 2.40 & 2.44 \\
\hline $\mathrm{P}_{2} \mathrm{O}_{5}$ & 1.92 & 1.97 & 0.86 & 0.89 & 0.98 & 1.04 & 0.47 & 0.49 & 1.31 & 1.40 & 0.64 & 0.66 & 1.17 & 1.19 \\
\hline $\mathrm{NiO}$ & - & - & - & - & - & - & 0.02 & 0.02 & - & - & 0.02 & 0.02 & & \\
\hline \multirow[t]{2}{*}{$\mathrm{Cr}_{2} \mathrm{O}_{3}$} & - & - & - & - & - & - & 0.04 & 0.04 & - & - & 0.04 & 0.04 & & \\
\hline & $\overline{97.48}$ & $\overline{99.99}$ & $\overline{96.71}$ & $\overline{99.99}$ & $\overline{94.62}$ & $\overline{100.01}$ & $\overline{95.30}$ & $\overline{99.99}$ & 93.57 & 100.00 & 97.15 & 99.99 & 98.05 & 99.98 \\
\hline AP & 4.12 & 4.12 & 1.90 & 1.90 & 2.23 & 2.23 & 1.05 & 1.05 & 2.99 & 2.99 & 1.39 & 1.39 & 2.53 & 2.53 \\
\hline IL & 2.71 & 2.71 & 5.82 & 5.82 & 5.03 & 5.03 & 7.41 & 7.41 & 6.58 & 6.56 & 2.89 & 2.89 & 5.44 & 5.44 \\
\hline OR & 11.29 & 11.29 & 10.91 & 10.91 & 5.63 & 5.63 & 9.23 & 9.23 & 14.69 & 14.69 & 2.70 & 2.70 & 14.69 & 14.69 \\
\hline $\mathrm{AB}$ & 50.69 & 54.54 & 14.25 & 21.08 & 34.46 & 34.47 & 8.46 & 15.27 & 34.04 & 35.73 & 31.83 & 31.83 & 34.73 & 40.17 \\
\hline AN & 15.36 & 15.36 & 24.17 & 24.17 & 23.70 & 23.69 & 24.13 & 24.13 & 22.45 & 22.45 & 23.80 & 23.80 & 23.10 & 23.10 \\
\hline WO & & 4.52 & & & & 4.52 & & & & & & 11.10 & & \\
\hline MT & & 2.63 & & 5.46 & & 6.10 & & & & 5.71 & & 3.98 & & 5.38 \\
\hline \multicolumn{15}{|l|}{ HM } \\
\hline FS & & 1.38 & & & 9.49 & 4.46 & & & & 1.96 & 3.45 & 5.06 & & .70 \\
\hline EN & & 2.25 & & & 5.30 & 9.29 & & & & 6.76 & 4.11 & 15.49 & & 1.37 \\
\hline Q & & & & & & 4.43 & & & & & & 1.52 & & \\
\hline $\mathrm{Di}$ & 9.04 & & 19.96 & 19.96 & 9.00 & & 24.06 & 24.06 & 2.96 & 2.96 & 22.21 & & 2.36 & 2.36 \\
\hline FO & .83 & & 9.51 & 7.63 & 1.79 & & 8.06 & 5.46 & 5.53 & .10 & 4.01 & & 4.03 & 2.68 \\
\hline FA & 2.46 & & 8.48 & 2.16 & 3.20 & & 6.68 & 1.10 & 9.59 & .03 & 3.38 & & 9.66 & 1.37 \\
\hline $\mathrm{NE}$ & 3.43 & 1.12 & 4.80 & .71 & & & 10.78 & 6.69 & 1.01 & & & & 3.27 & \\
\hline \multicolumn{15}{|l|}{$\begin{array}{l}\text { LC } \\
\text { KP }\end{array}$} \\
\hline & 99.91 & 99.91 & 99.79 & 99.88 & 99.83 & 99.82 & 99.86 & 99.86 & 99.84 & 99.84 & 99.75 & 99.75 & $\overline{99.80}$ & 99.80 \\
\hline
\end{tabular}

had $3 \%$ to $5 \%$ combined water. Such rocks whose analyses total $94 \%$ are probably moderately altered. These numbers are necessarily more vague than those given for rocks lacking amphiboles or micas. All norms were derived from analyses recalculated to $100 \%$ to offset some of the effects of alteration when intercomparisons are made.

Norms listed in Tables 2 and 3 are calculated with all iron as $\mathrm{FeO}$, and with $\mathrm{FeO} / \mathrm{Fe}_{2} \mathrm{O}_{3}$ adjusted to that of comparable average Hawaiian lavas given by Macdonald (1968). The potassic mafic lavas of Table 2 have no counterparts in the Hawaiian Islands, and the potassic rocks usually contain much completely altered olivine. Therefore, the adjusted norms for these rocks (Table 2) are calculated with $4 \%$ additional $\mathrm{MgO}$. The value of normative calculations of badly altered rocks is questionable at best, but some indications of the degree of silica undersaturation can be obtained by exercises of this type.

\section{Chemical Composition and Petrography of the Potassic Nephelinites}

It is convenient to discuss the unusual potassic mafic lavas first and the remainder of the rocks later. As listed in Table 1, potassic lavas were dredged from four localities, three of which provided sufficient material for analysis. The first four analyses given in Table 2 are from the Line Islands seamounts. An additional rock is described from a guyot in the Wake Seamounts and its analysis given in column 5. Columns 6-10 of Table 2 give analyses of continental lavas with similar characteristics taken from the literature. The detailed descriptions of the Line Islands and Wake potassic nephelinites are given in Appendix A. The reader is referred to Table 1 for precise dredge locations.

The potassic nephelinite samples dredged from Line Islands and Wake seamounts are characterized by high $\mathrm{K}_{2} \mathrm{O} / \mathrm{Na}_{2} \mathrm{O}, \mathrm{Al}_{2} \mathrm{O}_{3}, \mathrm{CaO}$, and $\mathrm{FeO}^{*}$ (see Table 2 and Appendix A). Of these, only $\mathrm{K}_{2} \mathrm{O} / \mathrm{Na}_{2} \mathrm{O}$ is likely to be affected by alteration. Most of the lavas have low $\mathrm{SiO}_{2}$ and high $\mathrm{P}_{2} \mathrm{O}_{5} . \mathrm{Sr}, \mathrm{Ba}, \mathrm{Zr}$, and $\mathrm{Rb}$ (Table 4) are all high. These characteristics are shared by their African counterparts (see Table 2). The Wake Guyot sample is more siliceous than those from the Line Islands seamounts but has petrographic features in common, namely abundant titanaugite and amphibole (see Plates 1-4). The features which distinguish these lavas from nephelinites of oceanic islands are high $\mathrm{Al}_{2} \mathrm{O}_{3}$ combined with low $\mathrm{SiO}_{2}$, high $\mathrm{K}_{2} \mathrm{O} / \mathrm{Na}_{2} \mathrm{O}$, and abundant amphibole or biotite in addition to olivine. The nephelinites of the Hawaiian and Samoan islands have lower $\mathrm{Al}_{2} \mathrm{O}_{3}$ and somewhat higher $\mathrm{SiO}_{2}$, with the exception of the melilite-bearing nephelinites, found only on Oahu and $\mathrm{Kauai}$, which have very low values of $\mathrm{Al}_{2} \mathrm{O}_{3}$ (less than $10 \%)$ and very low values of $\mathrm{SiO}_{2}$ (36-39\%). The difference in $\mathrm{Al}_{2} \mathrm{O}_{3}$ explains the presence of melilite in Hawaiian posterosional lavas, and the lack of it in the Line Islands potassic lavas. $\mathrm{CaO}$ is considerably higher 
TABLE 3 - Continued

\begin{tabular}{|c|c|c|c|c|c|c|c|c|c|c|c|c|c|}
\hline \multicolumn{2}{|c|}{$133-23$} & \multicolumn{2}{|c|}{$137-1$} & \multicolumn{2}{|c|}{$137-11$} & \multicolumn{2}{|c|}{$142-1$} & \multicolumn{2}{|c|}{ MP-25-F-2-1 } & \multicolumn{2}{|c|}{$144-2$} & \multicolumn{2}{|c|}{ A-5-19-1 } \\
\hline 46.10 & 48.34 & 54.10 & 58.46 & 53.90 & 57.29 & 58.20 & 59.70 & 44.40 & 46.10 & 45.40 & 47.75 & 57.20 & 60.18 \\
\hline 4.17 & 4.37 & 0.45 & 0.48 & 0.45 & 0.48 & 1.05 & 1.08 & 3.63 & 3.77 & 4.51 & 4.74 & 1.12 & 1.18 \\
\hline 15.00 & 15.67 & 21.00 & 22.47 & 20.40 & 21.66 & 16.80 & 17.29 & 15.20 & 15.73 & 13.60 & 14.26 & 18.50 & 19.47 \\
\hline 11.14 & 11.67 & 3.11 & 3.34 & 3.02 & 3.21 & 6.86 & 7.04 & 11.90 & 12.35 & 11.32 & 11.91 & 3.13 & 3.29 \\
\hline 0.13 & 0.14 & 0.23 & 0.25 & 0.22 & 0.23 & 0.19 & 0.20 & 0.15 & 0.16 & 0.17 & 0.18 & 0.16 & 0.17 \\
\hline 5.12 & 5.36 & 0.80 & 0.86 & 0.70 & 0.74 & 0.90 & 0.92 & 6.30 & 6.54 & 5.20 & 5.47 & 1.07 & 1.13 \\
\hline 8.81 & 9.23 & 1.04 & 1.11 & 0.95 & 1.01 & 4.14 & 4.25 & 9.41 & 9.77 & 9.51 & 10.01 & 2.65 & 2.79 \\
\hline 3.00 & 3.14 & 6.37 & 6.83 & 7.91 & 8.41 & 5.52 & 5.67 & 2.66 & 2.76 & 3.00 & 3.16 & 6.30 & 6.62 \\
\hline 1.44 & 1.51 & 5.72 & 6.13 & 6.35 & 6.75 & 3.49 & 3.58 & 2.07 & 2.15 & 1.46 & 1.54 & 4.71 & 4.95 \\
\hline \multirow[t]{3}{*}{0.54} & 0.57 & 0.07 & 0.08 & 0.21 & 0.22 & 0.26 & 0.27 & 0.66 & 0.68 & 0.87 & 0.92 & 0.21 & 0.22 \\
\hline & & & & & & & & & & 0.02 & 0.02 & & \\
\hline & & & & & & & & & & 0.05 & 0.06 & & \\
\hline 95.45 & 100.00 & 93.29 & 100.01 & 94.11 & 100.00 & 97.39 & 100.00 & 96.38 & 100.01 & 95.11 & 100.01 & 95.05 & 100.00 \\
\hline 1.20 & 1.20 & 0.15 & 0.15 & 0.45 & & 0.56 & 0.56 & 1.45 & 1.45 & 1.95 & 1.95 & .45 & \\
\hline 6.18 & 6.18 & 0.65 & 0.65 & 0.64 & & 1.49 & 1.49 & 5.31 & 5.31 & 6.74 & 6.74 & 1.60 & \\
\hline 9.05 & 9.05 & 34.97 & 34.98 & 38.00 & & 21.04 & 21.04 & 12.83 & 12.83 & 9.25 & 9.25 & 28.48 & \\
\hline 28.65 & 28.65 & 39.54 & 42.26 & 26.75 & & 50.56 & 50.56 & 16.49 & 22.55 & 28.68 & 28.87 & 48.81 & \\
\hline \multirow[t]{4}{*}{24.57} & 24.57 & 4.87 & 4.87 & 1.33 & & 11.08 & 11.08 & 24.45 & 24.45 & 20.57 & 20.57 & 8.53 & \\
\hline & 7.27 & & & & & & 3.26 & & & & 9.56 & & \\
\hline & 5.16 & & 1.31 & & & & 2.76 & & 4.84 & & 4.69 & & \\
\hline & & & .85 & & & & 1.92 & & & & & & \\
\hline 1.34 & 1.85 & & & & & 6.73 & & & & & 2.67 & & \\
\hline 1.66 & 15.04 & & & & & 1.83 & 2.53 & & & & 15.40 & & \\
\hline & .93 & & & & & & 4.66 & & & & .15 & & \\
\hline 14.53 & & & & 1.64 & & 6.51 & & 16.00 & 16.00 & 19.13 & & 2.82 & \\
\hline 7.03 & & 1.72 & 1.72 & 1.27 & & 0.01 & & 10.30 & 8.85 & 7.52 & & 1.77 & \\
\hline \multirow[t]{3}{*}{5.69} & & 3.25 & & 2.66 & & 0.04 & & 7.92 & 2.10 & 5.90 & & 1.97 & \\
\hline & & 11.78 & 10.15 & 27.10 & & 0.04 & & 5.14 & 1.50 & .11 & & 5.45 & \\
\hline & & 2.88 & 2.88 & & & & & & & & & & \\
\hline 99.89 & 99.89 & $\overline{99.81}$ & $\overline{99.81}$ & $\overline{99.83}$ & & $\overline{99.85}$ & $\overline{99.86}$ & $\overline{99.88}$ & $\overline{99.87}$ & $\overline{99.86}$ & $\overline{99.86}$ & $\overline{99.87}$ & \\
\hline
\end{tabular}

Note: 1 st column norms reduced; second column $\mathrm{FeO} / \mathrm{Fe}_{2} \mathrm{O}_{3}=1.8$ for basalts; 1.5 for hawaiites, mugearites; 0.4 for trachytes.

(After Macdonald, 1968, average Hawaiian lavas.)

in the Line Islands lavas than in typical Hawaiian and Samoan nephelinites, but again the Hawaiian melilitebearing lavas are almost as cafemic as the Line Islands lavas. The essential petrographic characteristics common to the Line Islands potassic lavas and typical oceanic island posterosional suites are the dominance of pinkish-brown titanaugite and the low abundance of plagioclase. However, the Line Islands lavas contain abundant amphibole and biotite; the Hawaiian posterosional lavas seldom do. The associated xenolith suites differ considerably. Xenoliths in the Hawaiian and Samoan suites are tectonized peridotites, generally lherzolites and dunites. In both localities the xenoliths are probably the ultramafic residua left from previous expulsion of basalts to form shield volcanoes (Jackson and Wright, 1970; Hawkins and Natland, 1975). The xenoliths in the Line Islands potassic lavas contain amphibole or biotite, which are present but extremely sparse in the Hawaiian xenoliths and have not been seen in Samoan xenoliths collected by this author. Although some of the Line Islands chain xenoliths appear granulated to some extent, they come from considerably shallower levels than the oceanic island xenolith suites. They do not contain aluminous orthopyroxene or garnet, for example, the principal high pressure mineral phases found in the Hawaiian xenoliths. Rather rare plagioclase occurs in some of the xenoliths, indicating a depth of origin less than about $30 \mathrm{~km}$.
The xenoliths in the Line Islands potassic nephelinites appear to be at least partly comagmatic with the lavas. Not only are the amphiboles and micas they contain similar to phenocrysts in the lavas, but the pyroxene phenocrysts in the lavas appear to be zoned from a xenolith-type pyroxene (pale green or dark green diopside or diopsidic augite) to brownish titanaugite (Plate 3, Figure 2). The biotite in the xenoliths contained in 134-1 appears to have formed within previously granulated pyroxenite, and is indistinguishable optically from biotite microphenocrysts and reaction rims around olivine in the lavas. The mica-bearing xenoliths are similar to some of the xenoliths included by Holmes and Harwood (1938) in their OBP (olivine-biotite-pyroxene) series of ejected mafic blocks. They suggested a model of petrogenesis which may also apply to the Line Islands potassic lavas. They do not describe amphibole-bearing lavas or xenoliths, but such lavas and xenoliths are known to occur in continental nephelinite suites (Varne, 1970; Dawson and Smith, 1973; Carmichael et al., 1974), and a comparable sequence of events can be constructed for these rocks.

Holmes and Harwood (1938) and Holmes (1952) distinguished two essential features of the chemistry of their African potassic lavas. The first, the high $\mathrm{K}_{2} \mathrm{O}$ / $\mathrm{Na}_{2} \mathrm{O}$, they attributed mainly to transfusion of incorporated granitic and gneissic continental crustal rocks. This is not possible for the Line Islands potassic lavas. 
TABLE 4

Minor Elements in Basaltic Rocks From the Line Islands and Wake Seamounts (values in ppm)

\begin{tabular}{lrrrrrrrrrrr}
\hline & $\mathrm{Ni}$ & $\mathrm{Cr}$ & $\mathrm{Co}$ & $\mathrm{V}$ & $\mathrm{Cu}$ & $\mathrm{Zn}$ & $\mathrm{Sr}$ & $\mathrm{Ba}$ & $\mathrm{Rb}$ & $\mathrm{Zr}$ & $\mathrm{Pb}$ \\
\hline $119-2$ & 24 & 17 & 45 & 15 & 15 & 105 & 970 & 365 & 30 & 350 & 2.0 \\
$128-1$ & 12 & 10 & 22 & 175 & 18 & 191 & 320 & 155 & 14 & 360 & 2.0 \\
$129-2$ & 135 & 290 & 54 & 230 & 112 & 142 & 2130 & 445 & 28 & 420 & 6.0 \\
$130-2$ & 70 & 110 & 56 & 280 & 43 & 96 & 750 & 340 & 35 & 255 & 4.0 \\
$133-9$ & 295 & 105 & 56 & 180 & 900 & 405 & 550 & 1390 & 32 & 250 & 13 \\
$133-21$ & 120 & 105 & 46 & 310 & 21 & 162 & 220 & 110 & 7 & 135 & 3.5 \\
$133-23$ & 240 & 75 & 50 & 210 & 36 & 172 & 465 & 340 & 33 & 215 & 5.0 \\
$134-1$ & 70 & 115 & 61 & 265 & 100 & 160 & 850 & 985 & 46 & 360 & 16 \\
$134-N$ & 150 & 130 & 88 & 365 & 59 & 146 & 230 & 1830 & 88 & 135 & 3.5 \\
$137-1$ & 34 & 4 & 4 & 20 & 37 & 192 & 1175 & 510 & 175 & 975 & 18 \\
$137-11$ & 65 & 13 & 16 & 18 & 23 & 126 & 1020 & 455 & 240 & 1025 & 13 \\
$142-1$ & 10 & 6 & 16 & 1 & 7 & 150 & 1090 & 860 & 33 & 550 & 13 \\
$144-2$ & 120 & 70 & 35 & 290 & 80 & 165 & 465 & 305 & 30 & 250 & 1.0 \\
A5-19 & 20 & 7 & 24 & 10 & 11 & 112 & 980 & 1950 & 117 & 610 & 11 \\
A5-25-1 & 85 & 40 & 35 & 145 & 48 & 109 & 980 & 615 & 64 & 365 & 19 \\
$122-1$ & & & & & & & & 590 & 23 & & \\
$123-15$ & & & & & & & & 430 & 40 & & \\
MP-25-F-2-1 & & & & & & & & 490 & 50 & & \\
$133-22$ & & & & & & & & 650 & 39 & & \\
\hline
\end{tabular}

Note: $\mathrm{Ba}$ and $\mathrm{Zn}$ done by $\mathrm{X}$-ray fluorescence. All others by atomic abosrpiton using method of standard additions for $\mathrm{Ni}, \mathrm{Cr}, \mathrm{Zn}$ and $\mathrm{Sr} . \mathrm{V}, \mathrm{Co}$, and $\mathrm{Pb}$ and low values of $\mathrm{Ni}$ determined using a heated graphite atomizer attachment to a Perkin-Elmer 403 spectrophotometer. Resolution: $\mathrm{Zr} \pm 15 \%, \mathrm{Rb}, \mathrm{Ba}, \mathrm{Ni} \pm 10 \%, \mathrm{~V}, \mathrm{Cr}, \mathrm{Co} \pm 5 \% ; \mathrm{Cu}, \mathrm{Sr}, \mathrm{Zn} \pm$ $3 \% ; \mathrm{Pb}<0.5 \mathrm{ppm}$.

The second is the combination of low $\mathrm{SiO}_{2}$ with high $\mathrm{Al}_{2} \mathrm{O}_{3}, \mathrm{CaO}$, and $\mathrm{FeO}^{*}$. This they inferred to reflect the chemical stamp of the biotite-bearing OBP xenoliths associated with the lavas. They argued that melting or partial melting of especially the hydrous phases of the xenoliths and incorporation into rising nephelinite melts produced the lavas. This of course deferred the problem of petrogenesis to the OBP series itself. Inasmuch as potassic nephelinites are usually smaller parts of much larger provinces of more typical sodic basanites and nephelinites, Holmes and Harwood argued that these more abundant sodic lavas could effectively soak a region of mantle, reacting with it to produce mantle biotite (and, we may infer, under appropriate stability conditions, amphibole), from which the OBP series was derived. The magma Holmes and Harwood chose to interact with the mantle in this way was a melilite-bearing nephelinite, not unlike those found on some oceanic islands. The granulated pyroxenites of the Line Islands cross-trend lava 134-1 assume a particular importance since they appear to have a second generation of biotite enclosing the fragmented pyroxenes. The mica could have resulted from the reaction of an olivine peridotite with an undersaturated, volatile-charged magma to produce the biotite pyroxenite. For the Line Islands potassic nephelinites, a possible sequence of events would be (1) generation of undersaturated nephelinite magmas by small degrees of partial melting at relatively great depths in the mantle $(50+\mathrm{km}$; O'Hara, 1968 ; Bultitude and Green, 1972); (2) a gradual rise of this melt material through the mantle, slow enough for it to react with its surroundings, stabilizing hydrous mantle phases in rather great abundance; (3) a continued rise in isotherms (either slowly or suddenly) causing incipient melting in the region of altered mantle; (4) these melts are assimilated into rising nephelinite magmas of more normal sodic character, leading to the generation of the observed lavas, with their unusual cafemic, aluminous and potassic chemical compositions. The presence of potassic nephelinites in an oceanic environment demonstrates that continental crust is not a necessary determinant in making them potassic, although it may be necessary to generate lavas as potassic as some of the East African rocks. The stabilization of potassium-rich amphiboles and micas in the melt source appears to be responsible for the potassium enrichment of the oceanic rocks.

If this sequence of events is correct, then the presence of these lavas corroborates tectonic models involving deep-seated small-scale melting, slow migration of melts and volatiles to the surface, gradual rise of isotherms, and small-scale remelting, all consistent with slow rupturing, uplift, rifting, and small volume volcanism in the Central Pacific along the Line Islands cross-trend. It must be stressed that the petrogenetic scheme listed above is hypothetical, based mainly on comparison to the East African lava and xenolith suites, and this interpretation is hampered by the small amounts and altered condition of the lavas dredged. The occurrence of potassic nephelinites in the Central Pacific, however, is of great interest because it demonstrates that interaction with continental crust is not required for the petrogenesis of potassic nephelinites, even in East Africa.

\section{Chemical Composition and Petrography of Other Lavas Dredged from the Line Islands Chain and the Mid-Pacific Mountains}

Detailed petrologic and compositional observations for all other lavas dredged from the Line Islands chain, plus two rocks from Horizon Guyot and Necker Ridge in the Mid-Pacific Mountains at the northern terminus of the Line Islands chain are given in Appendix B. The 
rocks include a wide spectrum of alkalic basalts, hawaiites, mugearites, trachytes, and phonolites. In addition, one further rock, a trachyte, from the Wake Guyots has been analyzed, and its description is also given in Appendix B and its composition in Table 3. Not all the rocks described have been analyzed, because many were considered too altered to yield representative analyses. Despite the extensive alteration, it is usually possible to estimate the lineage of the unanalyzed samples from the petrography, and rock names are assigned on this basis. Descriptions and analyses are listed sequentially by dredge number in Appendix B in order from south to north along the Line Islands chain. Precise locations are given in Table 1.

The analyses (Table 3) and descriptions (Appendix B) demonstrate that a wide variety of mafic and felsic rocks cap seamounts and ridges in the Line Islands chain and in nearby areas of the Central Pacific. These data are summarized in Figure 3, which shows trend lines for three progressively more alkalic series from the Samoan Islands drawn for comparison (Natland, 1975). The trends shown are two alkalic olivine basalt-hawaiitemugearite-trachyte series (Pago Pago and Fagaloa trends) and an olivine nephelinite-trachyandesitephonolite series (Samoan seamount trend, Hawkins, 1974). The three series correspond roughly to the mildly alkalic (or transitional), intermediate alkalic, and strongly alkalic trends of South Atlantic volcanic islands described by Baker (1973), and the same terminology will be applied to the Line Islands and related lavas using the Samoan grid. The Samoan trends are chosen for comparison because the differentiation sequences are relatively complete, the transitions to alkalic basalt compositions are well defined, and Samoan lavas are similar to Line Islands and vicinity lavas in several respects not shown by Hawaiian lavas, for example, high $\mathrm{TiO}_{2}$.

Among the felsic Line Islands lavas, both the mildly alkalic and intermediate alkalic trends are represented. Using the Samoan grid, lavas from dredges 119, 128, and 142 are mildly alkalic. Those of dredge 133 (four analyses) include a tholeiitic basalt (133-21) and three hawaiites which are arrayed nearly vertically on the diagram in a manner similar to the nearly vertical portions of the Samoan trends, which also range through basalt and hawaiite compositions. A similar trend was found for lavas from the Kalaupapa cliffs of Molokai, where the lavas range from transitional basalts at the base to alkalic basalts and hawaiites at the top (Beeson, 1973). Beeson has interpreted this trend as resulting from either relatively deep-seated clinopyroxene fractionation or progressively decreasing degrees of partial melting of a lherzolitic mantle. Either interpretation is consistent with a pattern of waning volcanism and removal of progressively smaller batches of basaltic magma from source regions in the mantle. This process allows stagnation and solidification of shallow magma pockets, resulting in the fractionation trends represented by the flatter parts of the curves.

Also plotted in Figure 3 is the field of Samoan posterosional basanites and nephelinites, erupted in a manner somewhat similar to Hawaiian posterosional volcanics, long after termination of the postcaldera felsic differentiate eruptive stage (Hawkins and Natland,
1975). The potassic nephelinites scatter generally throughout this region, but they are not strictly comparable to Hawaiian or Samoan posterosional lavas, as discussed earlier. Only Sample 130-2 is chemically comparable to the Samoan posterosional lavas. The socalled mugearites of DSDP Site 165 (Bass et al., 1973) are much more strongly alkalic and silica-undersaturated than Samoan or Hawaiian mugearites. They also contain minor amphibole, unlike true mugearites, but similar to the nepheline mugearites of Otago (Coombs and Wilkinson, 1969) and to the trachyandesites of Tahiti (Williams, 1933; McBirney and Williams, 1968). From their position in Figure 3, they could have a basanitic parent. This is borne out by their minor element compositions, especially their high $\mathrm{Ba}$ and $\mathrm{Sr}$ (Bass et al., 1973), which seem more consistent with a basanitic precursor than a basaltic one. Lavas from other DSDP sites are plotted in Figure 3. These include Site 170, which consists of basalts and mugearites from the Central Basin (within the cross-trend belt), and Site 171 (Horizon Guyot), which consists of highly altered tholeiites (enriched in $\mathrm{K}_{2} \mathrm{O}$ and $\mathrm{Na}_{2} \mathrm{O}$ by alteration; Bass et al., 1973). It is clear from lavas of these sites that alteration can produce inconsistencies as far as using total alkali content to determine tholeiitic chemistry. Alteration of the dredged rocks, though, appears to result in fewer such anomalies. Perhaps this is partly because deep burial of the DSDP lavas has resulted in metasomatism of $\mathrm{K}$ and $\mathrm{Na}$ during diagenesis (Kelts and McKenzie, this volume) whereas the dredged rocks have not been subjected to massive fluid flux, leaving trace element and major element chemistry closer to their original concentrations. A suite of transitional basalts was recovered at Site 315 from beneath the east Fanning Island fan; these lavas are described by Jackson et al. (this volume) and are inferred to be comparable to island edifice transitional basalts.

The phonolites from dredge 137 are similar to phonolites of the Samoan strongly alkalic trend (Figure 3). They contain abundant sanidine, up to $3 \%$ modal nepheline, and lesser haulyne. They also contain 5\%-10\% green aegerine augite, present as phenocrysts and as needles in the groundmass, and minor sphene. They are strongly undersaturated and presumably derived from a basanite or nephelinite parent, possibly represented by extremely altered hyaloclastites also recovered in the dredge haul. Although the seamount trends in a more northerly direction than ridges of the Line Islands cross trend (Winterer, this volume, fig. 1), it could date from the cross-trend period of volcanism (85-90 m.y. ago). However, the phonolites are not potassic and thus could not have had a potassic nephelinite parent.

The lavas from the inferred west end of the crosstrend, the Wake Guyots, include a potassic nephelinite (A-5-25-1) and a trachyte. The potassic nephelinite is a possible differentiate of a more olivine-rich potassic nephelinite, perhaps similar to those dredged from the Line Islands chain itself. The trachyte, which is quite fresh, is close to the Samoan intermediate series trachytes. Again, even in its western extremities, diverse petrology appears to characterize the cross-trend. Other lavas from the Wake Seamounts (listed in Natland, 1974) are olivine theralite $\left(21^{\circ} 09.6^{\prime} \mathrm{N}, 161^{\circ} 52.7^{\prime} \mathrm{E}\right)$; 


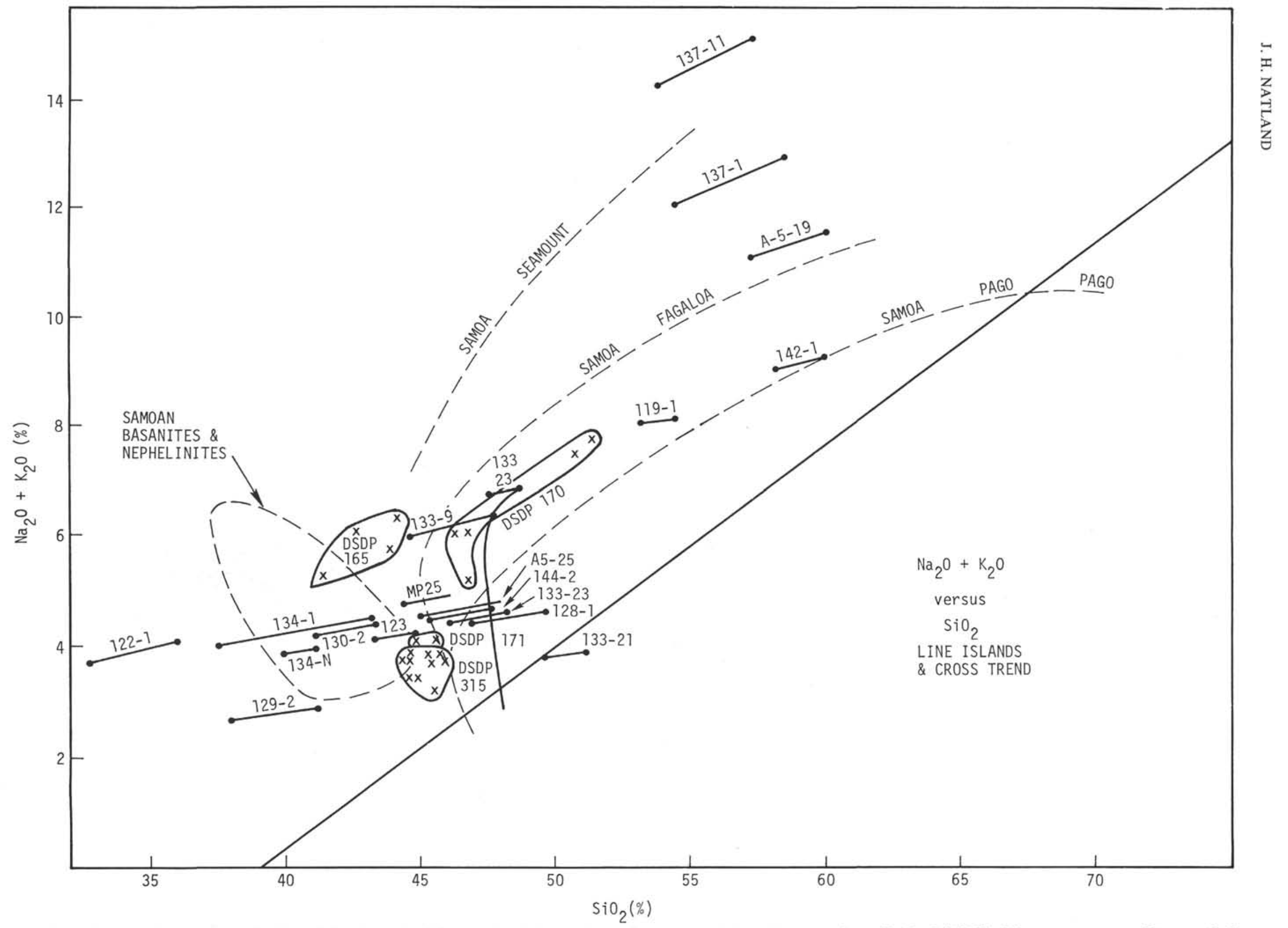

Figure 3. Alkalis-silica diagram for Line Islands dredged lavas. Trend lines shown for Samoan Island lavas are from Natland (1975). The seamount trend is provided through the courtesy of J. W. Hawkins, Jr. The field of Samoan basanites and nephelinites is based on data in Hawkins and Natland (1975) and Natland (1975). The Line Islands data are indicated by dredge and sample number. The lines connect "wet" and dry-reduced data points for each analysis. 
picrite $\left(21^{\circ} 09.0^{\prime} \mathrm{N}, 103^{\circ} 22^{\prime} \mathrm{E}\right)$; and several other possible potassic nephelinites $\left(23^{\circ} 48.9^{\prime} \mathrm{N}, 159^{\circ} 26.2^{\prime} \mathrm{E}\right.$ and $\left.24^{\circ} 0.5^{\prime} \mathrm{N}, 159^{\circ} 27.1^{\prime} \mathrm{E}\right)$. These rocks have not as yet been analyzed.

Figure 4 is a logarithmic $\mathrm{K}$ versus $\mathrm{Rb}$ diagram, again with the Samoan trends superposed. The ratio K/Rb has been used to estimate the presence of minor hydrous phases-amphibole or phlogopite-in the mantle (Klerkx et al., 1973; Hawkins and Natland, 1975). For mafic lavas, values of 500 or greater suggest amphibole in the mantle source material of the lavas; 300 or less is evidence for phlogopite, and, between, they may coexist (Klerkx et al., 1973). Shaw (1969) used the logarithmic plot to evaluate $\mathrm{K} / \mathrm{Rb}$ systematics. He discerned three types of K/Rb covariance: (1) a flat region with widely varying $K / R b$, the field of oceanic tholeiites (OT) and chondritic meteorites; (2) a shallow fractionation series, mainly, having a steeper slope called the main trend (MT); and (3) a late-stage hydrothermal-pegmatitic drop in $\mathrm{K} / \mathrm{Rb}$, (labeled $\mathrm{PH}$ ), which also can be produced by fractionation of potassic sanidine (see Clague, 1974). The Samoan curves are shown with the analogs of OT, MT, and PH indicated. The OT-type trend covers the range of hypersthene to nepheline normative basalts. The MT trend is the alkalic basalt-hawaiite-mugearitetrachyte series as well as the posterosional basanites and nephelinites. The seamount trend parallels the Samoan Island MT, but is offset and has a late PH hook. The offset main trends have been interpreted to imply that the seamount lavas stemmed from a parent that equilibrated in the mantle in the presence of amphibole, and the Samoan Main Trend in the presence of phlogopite (Hawkins and Natland, 1975). The Samoan OT analog reflects tapping of relatively $\mathrm{Rb}$-depleted mantle in the shield-building stages of volcanism.

The same types of variation can be seen in the Line Islands and vicinity lavas. Lavas from dredge 142 (trachytes) and DSDP Sites 165 and 170 (basalts labeled 170B) have considerably higher $\mathrm{K} / \mathrm{Rb}$ than the other Line Islands lavas. Most of the rest have values comparable to or slightly higher than the Samoan Main Trend, including the potassic nephelinites with the exception of 122-1, which falls within the field of DSDP Site 165 lavas. The mugearites from DSDP Site 170 $(170 \mathrm{M})$ are considerably offset from the basalts (170B) and are very rich in $\mathrm{Rb}$. Most of the Line Islands lavas fall between the seamount trend and the Samoan Main Trend, suggesting possible phlogopite control. Those to the left of the seamount trend (or its extrapolation to lower $\mathrm{K}$ and $\mathrm{Rb}$ ) indicate amphibole in the source region of the parental lavas.

It is possible that alteration has modified $\mathrm{K} / \mathrm{Rb}$ in some of the lavas. This is certainly true in the case of some of the low-Rb tholeiitic basalts, especially those from Site 170B, which were inferred to be oceanic tholeiites by Bass et al. (1973). These appear to have been enriched in K by alteration. Such K enrichment apparently has occurred in only one of the Horizon Guyot tholeiitic basalts (DSDP 171), causing it to lie above the flatter portion of the Samoan Islands trend. All others lie below, in the general region of oceanic tholeiites, indicating derivation from a source depleted in $\mathrm{Rb}$. The Horizon Guyot alkalic basalt (MP-25-2F-2), however, lies close to the Samoan Main Trend, suggesting derivation from an $\mathrm{Rb}$-enriched mantle source. The 170 basalts probably also were originally below the Samoan Island curve, indicating origin in a depleted mantle. The DSDP 170 mugearites, however, strikingly enriched in $\mathrm{Rb}$, must have come from a completely different (phlogopite-bearing) mantle source than these basalts which are depleted in $\mathrm{Rb}$.

Amphibole is apparently stable in the mantle only to depths of about $85 \mathrm{~km}$ (Lambert and Wyllie, 1968), suggesting a possible control on the depth of origin for some of the lavas. The trachyte of dredge 142, the "mugearites" of DSDP 165 and the potassic nephelinite $122-1$, should have stemmed from parents that equilibrated at mantle depths less than $85 \mathrm{~km}$. All other felsic lavas, then, appear to have been derived from parental lavas which equilibrated at greater depths, where only phlogopite was the stable hydrous mantle phase. The basalts of DSDP Sites 170 and 171, as well as the tholeiitic basalt 133-21, originated in "depleted" mantle, although the likelihood of significant modification of these low $\mathrm{Rb}$ lavas by sea-water alteration makes this interpretation uncertain. For the high $\mathrm{K}$ and $\mathrm{Rb}$ lavas such alteration is less likely to have modified the $\mathrm{K} / \mathrm{Rb}$ ratio significantly. The interplay of amphibole, phlogopite, and open- and closed-system processes operating in the upper mantle is only poorly known during conditions of mantle melting and mass transfer by convection, but it appears that some such interplay is required to explain many of the chemical variations shown by the Line Islands seamount and cross-trend lavas. The problem is especially complex for the amphibole-bearing lavas that contain amphibole pyroxenite xenoliths and yet have low $\mathrm{K} / \mathrm{Rb}$, suggesting phlogopite in the mantle source.

\section{IMPLICATIONS FOR TECTONICS}

Winterer (this volume) has summarized the age relations, bathymetric elements, and alternative tectonic models for the origin of the Line Islands chain. The petrologic data constrain these models somewhat, in that both the north-northwest main Line Islands ridges and west-northwest cross-trend ridges are dominantly island edifice tholeiitic or transitional (Jackson et al., this volume) to alkalic and strongly alkalic in character. This almost certainly precludes any ridge crest or abandoned ridge crest origin for either, assuming the likelihood that oceanic tholeiite and related lavas would predominate in such a setting.

Age determinations by Ozima and Saito (1974) and Lanphere and Dalrymple (this volume) leave open the possibility that the Line Islands chain is age progressive from the north (128 m.y.) to the south central region (86-90 m.y.) although the latter region is complicated by cross-trend bathymetry. The few ages available could be interpreted as consistent with the "hot spot" hypothesis, although they certainly do not prove it. The questionable assumption that chains produced by hot spots should have petrologic consistency (show a similar sequence of eruptives from volcano to volcano) may imply that the diverse Line Islands chain did originate in this way, unless two or more mantle melting anomalies were involved. 


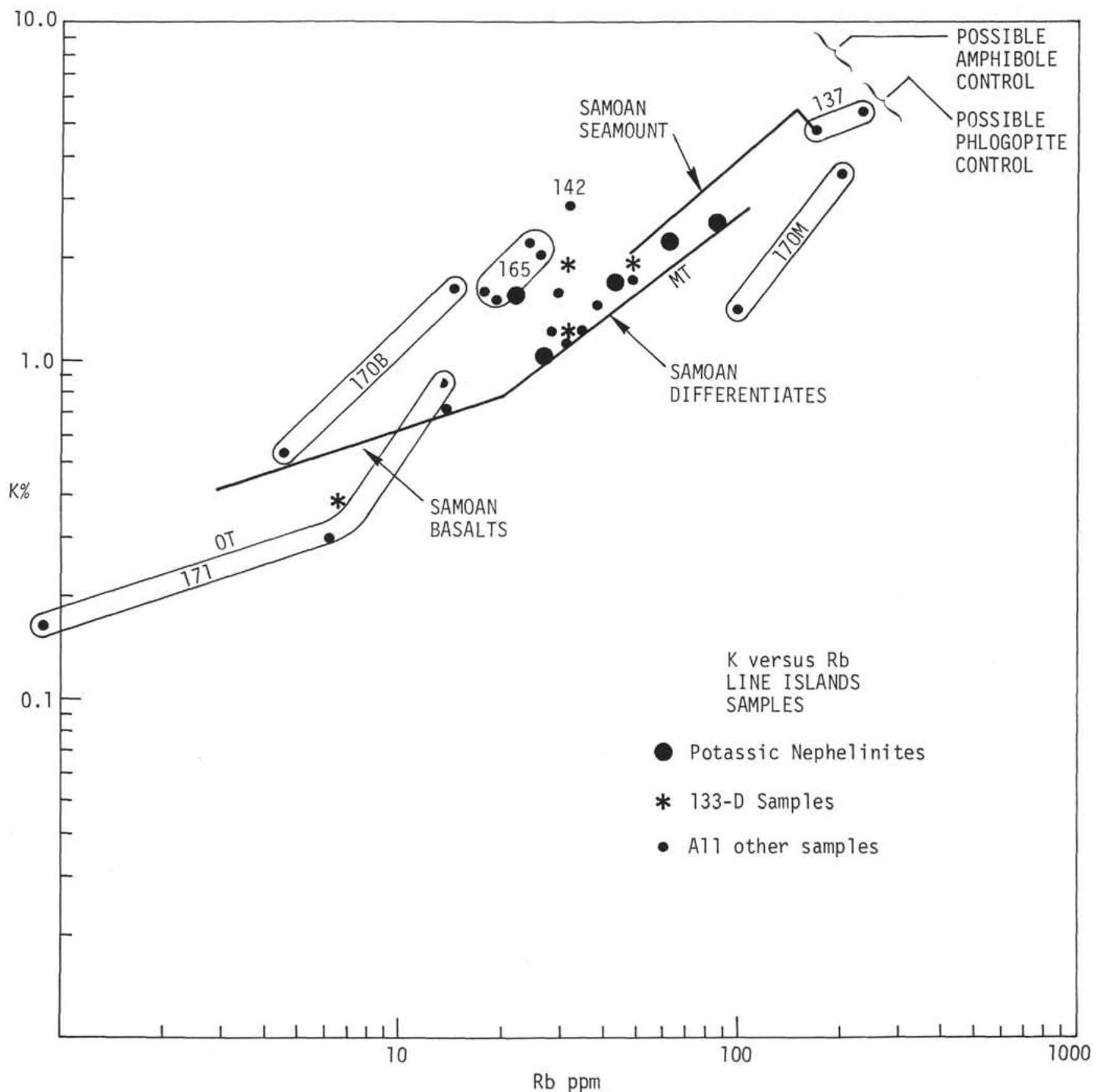

Figure 4. Logarithmic K-Rb diagram for dredged lavas. The trend lines for Samoan and seamount data are from Natland (1975). The general variation for oceanic tholeïtes (OT), and main fractionation trends (MT) are after Shaw (1969). Fields enclosing specific dredge hauls or DSDP sites are indicated by site number. Data for DSDP Sites 165, 170, and 171 from Bass et al. (1973). Small dots are basalts and differentiated lavas. Large dots are potassic nephelinites. Asterisks are from 7 TOW 6 Dredge 133, and include tholeiitic basalts and alkalic differentiated lavas. The general trends for phlogopite and amphibole control on K/Rb partitioning are based on the work of Shaw (1968), Klerkx et al. (1974), and Hawkins and Natland (1975).

The only group of rocks that gives a consistent clue to the tectonics of this region is the potassic nephelinites, which probably are restricted to the Line Islands crosstrend extending at least as far to the west as the Wake Guyots. These unusual lavas are found elsewhere only in regions of slow extensional volcanism, such as the rifts of East Africa. Earlier it was argued that the generation of potassic nephelinites in the Central Pacific probably required a modification of the upper mantle by melts and volatile-rich fluids derived from greater depths to establish abundant mantle hydrous phases, prior to remelting of this modified mantle to produce the potassic mafic lavas. Intrinsically, this process precludes involvement of large volumes of magma, a view substantiated by the strong enrichment of large radius cations $(\mathrm{K}, \mathrm{Rb}$, etc.) and strong silica undersaturation of the 
potassic nephelinites. The process envisioned to enrich the upper mantle in hydrous phases does not occur under oceanic islands such as the Hawaiian chain. Such volcanoes are built very rapidly. Typically, the tholeiitic portion of Hawaiin shield volcanoes (greater than $99 \%$ of the volumes of volcanoes) is built in less than a million years (Macdonald, 1968). A refractory mass of dunite and lherzolite almost totally depleted in volatile constituents is left beneath them (Jackson and Wright, 1970). The difference between the Line Islands and Hawaiian volcanoes may therefore be that the thermal convective event causing the Hawaiian volcanoes is highly focused, whereas that of the Line Islands potassic nephelinite volcanoes is widely dispersed. This dispersed thermal anomaly allows the formation of voluminous hydrous phases to occur in the upper mantle before that zone of mantle is involved in a melting episode.

Thus the potassic nephelinites favor tectonic model involving broad regional increases in geothermal gradients such as that which accompanies the warping and doming associated with rift valleys. If this is consistent with migration of the Pacific plate over mantle "hot spots" or melting anomalies, as suggested by Winterer (this volume), then the hot spots must be considerably weaker than those which produce oceanic islands like Hawaii. It is more likely that such inferred broad regional warping, cracking, and volcanism should not be construed in terms of "hot spots" any more than should the rift zone of East Africa.

\section{ACKNOWLEDGMENTS}

This report would not have been possible without the successful dredging operations undertaken by the Master and crew of the R/V Thomas Washington, and most especially, George Hohnhaus, who supervised the dredging. My thanks to E. L. Winterer, who made the dredge hauls available for this study and who has provided much insight into the possible tectonic significance of the rocks in many discussions. My thanks also to E.D. Jackson and D.A. Clague, who reviewed the manuscript; and to J.W. Hawkins, Jr., my advisor throughout the course of this work. Roy and Betty DeHaven provided numerous high-quality thin sections, for this study, made from extremely fragile material in many cases. R. LaBorde assisted in the analytic work.

\section{REFERENCES}

Baker, P.E., 1973. Islands of the South Atlantic. In Nairn, A.E.M and Stehli, F.S. (Eds.), The ocean basins and margins V.I. The South Atlantic: New York (Plenum Press), p. 493-554.

Bass, M.N., Moberly, R.M., Rhodes, J.M., and Shih, C., 1973. Volcanic Rocks cored in the Central Pacific Leg 17, Deep Sea Drilling Project. In Winterer, E.L., Ewing, J.I., et al., Initial Reports of the Deep Sea Drilling Project, Volume 17: Washington (U.S. Government Printing Office), p. 429-504.

Beeson, M.H., 1973. Petrology, mineralogy and geochemistry of the lavas of East Molokae Volcano, Hawaii: Unpublished Ph.D. Dissertation, University of California, Santa Cruz.

Bonatti, E., 1965. Palagonite, hyaloclastites, and alteration of volcanic glass in the ocean; Volcanol. Bull., v. 28, p. 3-15.

Brown, F.H., 1971. Volcanic petrology of the Toro-Ankale Region, Western Uganda: Ph.D. Dissertation, University of California, Berkeley.
Bultitude, R.J. and Green, D.H., 1971. Experimental study of crystal liquid relationships at high pressures in olivine nephelinite and basanite compositions: J. Petrol., v. 12, p. 121-147.

Carlisle, D., 1963. Pillow breccias and their aquagene tuffs in Quadra Island British Columbia: J. Geol., v. 71, p. 48-71.

Carmichael, I.S.E., Turner, F.J., and Verhoogen, J., 1974. Igneous petrology: New York (McGraw-Hill Book Co.), p. 739.

Clague, D.A., 1974. The Hawaiian Emperor Seamount Chain: its origin, petrology, and implications for plate tectonics: Ph.D. Dissertation, University of California, San Diego.

Coombs, D.S. and Wilkinson, J.F.G., 1969. Lineages and fractionation trends in undersaturated volcanic rocks from the East Otago volcanic province (New Zealand) and related rocks: J. Petrol., v. 10, p. 440-501.

Dawson, J.B. and Smith, J.V., 1973. Alkalic pyroxenite xenoliths from the Lashaine Volcano, Northern Tanzania: J. Petrol., v. 14, p. 113-131.

Hamilton, E.L., 1956. Sunken islands of the Mid-Pacific Mountains: Geol Soc. Am. Mem. 67.

Hawkins, J.W., 1974. Petrology of a differentiated alkalic rock series from a seamount near the Tonga Trench: Geol. Soc. Am. Abstracts with Programs, p. 189.

Hawkins, J.W. and Natland, J.H., 1975. Nephelinites and basanites of the Samoan linear volcanic chain: their possible tectonic significance: Earth Planet. Sci., Lett., v. 24, p. 427-439.

Heezen, B.C., Matthews, J.L., Catalano, R., Natland, J., Coogan, A., Thorp, N., and Rawson, M., 1973. Western Pacific guyots. In Heezen, B.C., MacGregor, I., et al., Initial Reports of the Deep Sea Drilling Project, Volume 20: Washington (U.S. Government Printing Office), p. 653-702.

Herlicksa, E., 1967. Selected trace elements in Hawaiian lavas by atomic absorption spectrophotometry: Ph.D. thesis, University of Hawaii, Honolulu.

Holmes, A., 1952. The Potash Ankaratrite-melaleucitite lavas of Nabugando and Mbuga Craters, Southwest Uganda: Geol. Soc. Edin. Trans., v. 15, p. 187-213.

Holmes, A. and Harwood, H.F., 1938. The volcanic area of Bufumbira: Pt. II, the petrology of the volcanic field of Bufumbira, South-West Uganda and of other parts of the Birunga field: Geol. Surv. Uganda, Mem. 3.

Hubbard, N.J., 1969. A chemical comparison of oceanic ridge, Hawaiian tholeiitic and Hawaiian alkalic basalts: Earth Planet. Sci., Lett., v. 5, p. 346-352.

Jackson, E.D. and Wright, T.L., 1970. Xenoliths in the Honolulu volcanic series: J. Petrol., v. 11, p. 405-430.

Jackson, E.D., Silver, E.A., and Dalrymple, G.B., 1972. Hawaiian-Emperor Chain and its relation to Cenozoic Circum-Pacific tectonics: Geol. Soc. Am. Bull., v. 83, p. 601-618.

Klerkx, J., Deutsch, S., and DePaepe, P., 1974. Rubidium, strontium content and strontium isotopic composition of strongly alkalic basaltic rocks from the Cape Verde Islands: Contrib. Mineral. Petrol., v. 45, p. 107-118.

Lambert, I.B. and Wyllie, P.J., 1968. Stability of hornblende and a model for the low velocity zone: Nature, v. 219, p. 1240.

Lonsdale, P., Normark, W., and Newman, W., 1972. Sedimentation and erosion on Horizon Guyot: Geol. Soc. Am. Bull., v. 83, p. 289-316.

Macdonald, G.A., 1968. Composition and origin of Hawaiian lavas: Geol. Soc. Am. Mem. 116, p. 477-522.

Macdonald, G.A. and Katsura, T., 1964. Chemical compositions of Hawaiian lavas: J. Petrol., v. 5., p. 82-133.

McBirney, A.R. and Williams, H., 1968. Geology and petrology of the Galápagos Islands: Geol. Soc. Am. Mem. 118 , p. 197. 
McDougall, I., 1964. Potassium-argon ages of the Hawaiian Islands: Geol. Soc. Am. Bull., v. 75, p. 107-128.

Modreski, P.J. and Boettcher, A.L., 1972. The stability of phlogopite and enstalite at high pressures: a model for micas in the interior of the Earth: Am. J. Sci., v. 272, p. 852-869.

Natland, J., 1974. Geology and tectonics of the Fagaloa shield volcano, island of Upolu, Western Samoa: plate bending, faulting, and possible shear melting north of the Tonga Trench: Geol. Soc. Am., Abstracts with Programs, v. 6, p. 226.

1975. Petrologic studies of Linear Island Chains: Part I The Samoan Islands; Part 2: The Line Islands: Ph.D. Dissertation, University of California, San Diego.

O'Hara, M.J., 1968. The bearing of phase equilibria studies in synthetic and natural systems on the origin and evolution of basic and ultrabasic rocks: Earth Sci. Rev., v. 4, p. $69-$ 133.

Ozima, M. and Saito, K., 1974. ${ }^{40} \mathrm{Ar} /{ }^{39} / \mathrm{Ar}$ ages of some submarine rocks and their geophysical implications (abstract): Abstracts with Program, Internatl. Woollard Symp., Hawaii Inst. Geophys., p. 33.

Shaw, D.M., 1968. A review of K-Rb fractionation trends by covariance analysis: Geochim. Cosmochim. Acta, v. 32, p. 573-601.

Varne, R., 1970. The petrology of Morotu Mountain: Eastern Uganda and the origin of nephelinites: J. Petrol., v. 9, p. 850 .

Winterer, E.L., Ewing, J.I., et al., 1973. Initial Reports of the Deep Sea Drilling Project, Volume 17: Washington (U.S. Government Printing Office).

Williams, H., 1933. Geology of Tahiti Moorea and Maiao: B.P. Bishop Mus. Bull. 105.

\section{APPENDIX A}

\section{TOW 6-122-D Potassic Nephelinite (Plate 1, Figure 1)}

Pillow breccias were dredged from the base of a pelagic sediment cap atop a ridge with an overall west-northwest trend in the central Line Islands chain (Natland, Chapter 27 this volume). This ridge is in a complex zone of west-northwest, north-northwest, or other-trending ridges and peaks and cannot definitely be assigned to the Line Islands cross-trend on the basis of the limited survey undertaken before and after dredging.

The lithic clasts embedded in the hyaloclastites or found as separate manganese-oxide-crusted boulders are hyalopilitic, dark brownishgray, and badly altered. All are vesicular with one sample containing vesicles up to $1 \mathrm{~cm}$ in size. Microphenocrysts of olivine altered to clays and reddish hydrous iron oxides form up to $15 \%$ of the rocks and are readily seen in the hand specimens. In thin section, the most abundant primary mineral consists of microphenocrysts and stubby groundmass crystals of pale pinkish-brown titanaugite. Opaques, probably titanomagnetite, are abundant, and form linked chains which cross in trellised arrays, a characteristic of such minerals in quickly quenched submarine lavas. In the less glassy interior portions of the larger rock fragments recovered, opaque minerals form isolated cubes, octahedra, and needles. Feldspar is very rare, but isolated tiny twinned grains of andesine can be found, as well as murky patches of alkali feldspar (potash oligoclase?) riddled with needles of apatite. The principal reason for the low total of the specimen analyzed is the water contained in altered olivine, but phillipsite lines virtually every vesicle, and must add considerable water to the rock as well. The extremely high $\mathrm{P}_{2} \mathrm{O}_{5}$ content of the analysis may be due partly to contamination with marine phosphorite, which fills vesicles in the outer rinds of the larger lithic clasts. Special care was taken to avoid such portions of the sample prepared for analysis, and it is concluded that much of the $\mathrm{P}_{2} \mathrm{O}_{5}$ must be primary. Needles of apatite can be seen in the alkali feldspars of the thin sections and are probably abundant in the ubiquitous dark brown glass of the groundmass. Possibly marine phosphorite was assimilated by the flow after extrusion.

The analysis of this rock shows it to be extremely low in $\mathrm{SiO}_{2}$, but with surprisingly high $\mathrm{Al}_{2} \mathrm{O}_{3}, \mathrm{CaO}$, and $\mathrm{FeO}^{*}$. Leucite appears in the reduced norm, and kaliophilite in the norm with $4 \%$ additional $\mathrm{MgO}$. $\mathrm{K}_{2} \mathrm{O}$ is high relative to $\mathrm{Na}_{2} \mathrm{O}$, but does not exceed it. A comparable lava from S.W. Uganda's Katwe-Kikorongo volcanic field, is listed in column 6 of Table 2 (Holmes, 1952). It is a melaleucitite but with higher $\mathrm{K}_{2} \mathrm{O}$ than 122-1. Combined water and $\mathrm{CO}_{2}$ form almost $6 \%$ of the analysis and $\mathrm{Fe}_{2} \mathrm{O}_{3} / \mathrm{FeO}$ is high. Holmes' description of the rock indicates that it is fresh. The total of $92.7 \%$ given for analysis $122-1$ may thus indicate a fairly fresh rock if the $\mathrm{H}_{2} \mathrm{O}$ and $\mathrm{CO}_{2}$ contents are similar to the Holmes' analysis.

\section{TOW 6 129-D Potassic Nephelinite (limburgite) (Plate 1, Figure 3;} Plate 5, Figures 3-5)

Two types of lavas were dredged at this site, dark brown, nonvesicular porphyritic rocks, and dark brown, nonporphyritic, slightly vesicular, flow-textured rocks, both embedded in hyaloclastites.

The porphyritic rocks have about $20 \%$ brownish-pink titanaugite phenocrysts, some with green augitic cores, about $5 \%$ altered olivine phenocrysts (now clays and iron hydroxides), about $10 \%$ fresh brown pleochroic amphibole phenocrysts, and rare darker amphibole phenocrysts with ravelled edges and abundant exsolved opaques, possibly indicating reaction with the surrounding melt. These sometimes enclose cigar-shaped apatite crystals. A few xenoliths are present, $1-2 \mathrm{~cm}$ in size, and contain a similar fibrous amphibole interlocked with pale green augite crystals of about the same size, up to $2 \mathrm{~mm}$. The groundmass of the lava is mostly titanaugite $\left(2 \mathrm{~V}^{+}=30^{\circ}\right)$ with about $10 \%$ andesine and 5\% olivine altered to iddingsite, intersertally arranged in abundant glass clouded with secondary minerals, chiefly finely disseminated clays. Titanomagnetite and perovskite dot the groundmass. Analysis 129-1 (column 2, Table 2) is one of the porphyritic lavas, which are generally fresher than the more glassy lavas. The analysis is similar to $122-1$ in its low $\mathrm{SiO}_{2}$, high $\mathrm{Al}_{2} \mathrm{O}_{3}, \mathrm{CaO}, \mathrm{FeO}^{*}$, and $\mathrm{P}_{2} \mathrm{O}_{5}$. Allowing for the alteration of the olivines, the rock was probably originally nepheline normative. $\mathrm{Sr}, \mathrm{Ba}$, and $\mathrm{Zr}$ are very high, reflecting both high apatite and titanaugite contents.

The porphyritic rocks are virtually identical to the porphyritic lavas, except they have fewer green augite-cored titanaugite phenocrysts, no xenoliths, no plagioclase, and more abundant glass. They may represent the more quickly cooled portions of the submarine flow, with the phenocryst and xenolith-rich, plagioclase-bearing lavas being the more slowly and completely cooled flow interiors.

Hyaloclastites in the dredge haul contain sand-sized grains of these rocks and minerals, plus grains of sanidine, ferrosalite, and a felsic rock with abundant oligoclase, possibly mugearite of the Hawaiian type, or a more alkalic variant.

7 TOW 6-134-D Potassic Nephelinite (ankaratrite) (Plate 1, Figures 58; Plate 2)

These rocks, aquagene tuffs, were dredged from a seamount abutting a major west-northwest-trending ridge to the north. The rocks are dark gray, nonvesicular, and pitted with rusty iron hydroxides altered from phenocrysts of olivine. The rock analyzed (134-1, column 3, Table 2) has about $10 \%$ phenocrysts of brownish titanaugite, some with green augitic cores, and an equivalent proportion of altered olivine phenocrysts (to clays and iron hydroxides). The olivines sometimes enclose smaller crystals of green augite or salite $\left(2 \mathrm{~V}+=60^{\circ}\right)$ and titanaugite $\left(2 \mathrm{~V}^{+}\right.$as low as $\left.20^{\circ}\right)$ and a pleochroic pale yellow to brown biotite mica with a small negative optic angle near $10^{\circ}$. The pyroxenes and biotite are in possible reaction relationship to produce olivine plus liquid (Modreski and Boettcher, 1973). The most common mica-olivine relationship, however, is olivine with a reaction rim of biotite. A few relict unaltered olivines are iron rich (approximately Foss). The groundmass has about $25 \%$ brown titanaugite with $3 \%-5 \%$ leucite (?) hexagonal rounded pseudomorphs replaced by phillipsite (identified by X-ray), iddingsite after olivine, and opaques, all set in a deep brown glass. Opaques are cubic or octahedral crystals, sometimes in linked chains, probably titanomagnetite. Perovskite is also present, but is less abundant than the opaque crystals. Occasional microphenocrysts of apatite, rare sanidine, and zircon are also present. The sanidine may be xenocrystal, as an interlocking mosaic of sanidine and leucite about $0.5 \mathrm{~cm}$ in diameter was found in one thin section (Plate 3, Figures 7,8 ). This appears to be an accidental inclusion of a leucite phonolite.

In addition to the possible felsic xenocrysts, the rock carries abundant microxenoliths of interlocking green augite, biotite, and rare plagioclase. The pyroxene has a somewhat granulated appearance; euhedra are rare. The biotite is irregular, but well formed and not granulated. It surrounds zones and patches of the granulated pyrox- 
enes and appears to have formed after the pyroxenes were disrupted. These xenoliths are similar to biotite pyroxenites of the OBP series of Bufumbria, Uganda, described by Holmes and Harwood (1938).

Analysis 134-1 has a lower content of $\mathrm{Al}_{2} \mathrm{O}_{3}$ than does either 122-1 or 129-2, but is still cafemic, high in $\mathrm{CaO}$ and $\mathrm{FeO}^{*} . \mathrm{K}_{2} \mathrm{O}$ exceeds $\mathrm{Na}_{2} \mathrm{O}$, no doubt reflecting the abundance of potassic micas. The low total of the analysis confirms the petrographic evidence that the rock is badly altered. The olivines are replaced by hydrous clays and iron oxides, and phillipsite lines virtually every vesicle and is riddled throughout the groundmass, appearing to replace primary minerals, especially those with rounded hexagonal outline, possibly originally leucite or nepheline. Nepheline is high and albite low in the norm, reflecting both low $\mathrm{SiO}_{2}$ and $\mathrm{Al}_{2} \mathrm{O}_{3}$, and high alkalis, especially $\mathrm{K}_{2} \mathrm{O}$. Because of the extent of alteration, it is not possible to say whether the values given for the alkalis represent the unaltered rock, but the relative proportions are probably correct, and $\mathrm{K}_{2} \mathrm{O}$ may have originally exceeded $\mathrm{Na}_{2} \mathrm{O}$.

This is confirmed by the analysis of a pegmatoidal segregation found within 134-1. Its analysis, 134-N, is given in column 4 of Table 2. The pegmatoid is olivine free, comprised chiefly of titanaugite, with lesser titanbiotite, apatite, devitrified glass, and cavity-filling zeolites (phillipsite). This assemblage is distinctly coarser grained than that of the enclosing lava, with average grain size between 1 and $2 \mathrm{~mm}$. The low $\mathrm{Al}_{2} \mathrm{O}_{3}$ reflects the preponderance of clinopyroxene, but is high enough to indicate that the pyroxene must be aluminous. The high $\mathrm{K}_{2} \mathrm{O}$ is bound in the glass and micas. The mica also probably contains most of the Ba (see Table 4; Holmes and Harwood, 1938). Since pegmatoids tend to reflect residual chemistries and to parallel fractionation trends, the lavas from dredge 134 must be highly potassic, a feature that is probably obscured by alteration in 134-1, but is strikingly apparent in the much fresher 134-N.

With the exception of leucite, which may have been present prior to alteration, these rocks resemble biotite or phlogopite-bearing potash ankaratrites from East Africa described by Brown (1971) and later Carmichael et al. (1974) who gave the analysis in column 7 of Table 2. This analysis is extremely cafemic and much higher in $\mathrm{K}_{2} \mathrm{O}$ than the 134 rocks. Continental potassic nephelinites are often higher in $\mathrm{K}_{2} \mathrm{O}$ than the Line Islands potassic lavas, but a few have comparable $\mathrm{K}_{2} \mathrm{O} / \mathrm{Na}_{2} \mathrm{O}$ ratios. Two such lavas are listed in columns 8 and 9 of Table 2. That of column 8, from East Africa in particular resembles 129-2. Holmes and Harwood (1938) called such lavas murambites (or murambitoids, if they were too glassy to contain modal leucite). They are the least potassic of the suite of potassic lavas of East Africa and are most closely comparable to the Line Islands lavas in this respect. Lavas as undersaturated as 134-1 with comparable low alkalis have not been analyzed from East Africa. But Holmes and Harwood considered that the African lavas generally assimilated granite, gneiss, quartzite, and other continental crustal rocks, which they found as abundant transfused xenoliths and blocks within the lavas. The lavas were inferred to have assimilated much if not most of their $\mathrm{K}_{2} \mathrm{O}$ from the transfused rocks. The Line Islands potassic lavas may cover the spectrum of mafic chemistries found in East Africa, but never contain the high $\mathrm{K}_{2} \mathrm{O}$ of some of those lavas because continental crust is absent in the Central Pacific. The lavas are nevertheless extremely potassic as far as oceanic lavas go. They can therefore be interpreted as being as potassic as oceanic mafic lavas can be without the involvement of continental crust. Mechanisms for potassium enrichment compatible with the evolution of oceanic crust and mantle must be sought. Analyses 8 and 9 (Holmes' murambites) my represent lavas for which the same conditions applied in a continental regime.

7 TOW 6 138-D Potassic Nephelinite (limburgite) (Plate 3, Figures 2, 3)

Only a few grams of rock were recovered in this dredge haul from a west-northwest-trending ridge in the northern Line Islands crosstrend. Thin sections reveal them to be virtually identical to those dredged at Station 129-D. Gray and moderately porphyritic, they contain about $20 \%$ titanaugite phenocrysts, the larger ones cored with a deep green augite, possibly rich in aegerite. Also present are about $10 \%$ nonfibrous brown amphibole and rare dark brown fibrous amphibole enclosing apatite. These are comparable to the two amphiboles described from Station 129. There are also scattered olivine pseudomorphs, now clays and iron hydroxides. The groundmass is dominated by a pinkish-brown titanugite, with iddingsite after olivine, scattered cubic octahedral or needle-like opaques, probably titanomagnetite, and altered brown glass, stained to reddish hues where affected by palagonitization. The cuantity and quality of rocks dredged were insufficient for chemical analysis.
Aries 5-25 and 27 Potassic Nephelinites (absarokites) (Plate 3, Figures 4 and 5)

In addition to potassic mafic lavas dredged from the vicinity of the Line Islands, similar lavas have also been recovered from guyots in the Wake Seamounts, over $1000 \mathrm{~km}$ to the west. These were first described in a paper dealing with the origin and petrography of guyots of the western Pacific (Natland's section, in Heezen et al., 1973) but their potassic character was not known at the time. Because of their petrographic similarity to the Line Islands lavas described above, one of these lavas has now been analyzed (A-5-25-1, column 5, Table 2). Virtually identical lavas were recovered in a second dredge station on this seamount (Aries 5-27). Similar lavas were also dredged on Miami Guyot at $21^{\circ} 40^{\prime} \mathrm{N}, 161^{\circ} 50^{\prime} \mathrm{E}$, and on Makarov Guyot at $29^{\circ} 30^{\prime} \mathrm{N}$, $153^{\circ} 20^{\prime} \mathrm{E}$. Both of these guyots are on the extrapolated continuation of the Line Islands cross-trend into the western Pacific and occur in regions where west-northwest topography is prominent. The rocks from Miami and Makarov guyots have thus far not been analyzed.

The analyzed specimen from the Wake Guyots has minor altered olivine microphenocrysts and about $5 \%$ pink titanaugite phenocrysts, some of them with pale green diopsidic cores. The latter can be up to $0.5 \mathrm{~cm}$ in diameter. Smaller brown pleochroic amphibole phenocrysts are more common and in some cases are megacrystic, up to $3 \mathrm{~cm}$ in size. The groundmass of this rock is hyalopilitic and contains abundant titanaugite and much subordinant sodic plagioclase, including oligoclase and potash oligoclase, the latter riddled with needles of apatite. Cubic crystals of titanomagnetite and reddish-brown perovskite dot the groundmass. Nepheline is present, but very rare, and large, cigar-shaped grains of apatite are sometimes enclosed by amphibole or clinopyroxene. Alteration of this rock is primarily in the groundmass where glass is considerably replaced by clays. $\mathrm{K}_{2} \mathrm{O} / \mathrm{Na}_{2} \mathrm{O}$ is probably affected, but to an uncertain degree. It is probably not affected enough to obscure the potassic character of the lava.

The analysis is higher in $\mathrm{SiO}_{2}$ than the Line Islands seamount potassic nephelinites, and lower in $\mathrm{CaO}$ and $\mathrm{FeO}^{*} . \mathrm{Al}_{2} \mathrm{O}_{3}$ is very high. The rock is comparable in these respects to the shoshonitic absarokite reported by Holmes and Harwood (1938) from Mgahinga volcano, Bufumbira. Their rock is again a bit more potassic, possibly reflecting contamination with continental crust. The Wake Seamount rock reported here has virtually no phenocrystal olivine and may have been a differentiate from magma similar to the originally more magnesian Line Islands seamount specimens listed in Table 2. The low $\mathrm{CaO}$ and $\mathrm{FeO}^{*}$ are consistent with this interpretation.

\section{APPENDIX B}

\section{TOW 6-118-D Hawaiite}

This dredge haul and the next were across the summit of a seamount over a degree to the west of the southern Line Islands ridges. The crustal structure underlying the volcano has a grain paralleling the Phoenix magnetic lineations and the Nova-Canton Trough, a major fault structure in the ocean floor that has recently been traced all the way to the Line Islands (E.L. Winterer and B.R. Rosendahl, personal communication). The seamount may therefore be unrelated to the Line Islands chain.

In dredge 118, a dark brown lithic clast was dredged embedded in intensely altered light green hyaloclastite breccia, almost completely replaced by clays. The clast is less altered, fine grained, and trachytic in texture. Scattered labradorite phenocrysts $\left(A_{08}\right)$ up to $3 \mathrm{~mm}$ are set in a groundmass predominantly of slender andesine laths (Anso), magnetite, and minor augite. An alkali feldspar with low positive optic angle (potash oligoclase, Macdonald, 1968) is also present. On the basis of feldspar composition and presence of potash oligoclase, the rock is classified as hawaiite.

\section{TOW 6-119-D Mugearite (Plate 3, Figure 6)}

The second dredge across the summit of this seamount produced much fresher material than the first. One of the rocks was analyzed (analysis 119-1, column 1, Table 3). The rock is fine grained, light gray, and trachytic in texture. Phenocrysts of andesine are very sparse. The groundmass consists principally of slender oligoclase laths ( $\left.A_{n_{30}}\right)$, with interstitial potash oligoclase $\left(2 \mathrm{~V}+=10^{\circ}-30^{\circ}\right.$, patchy extinction), and minor clear augite. The total of the analysis is high, consistent with the rock's fresh appearance under the microscope. The analysis is slightly higher in $\mathrm{SiO}_{2}$ and total alkalis, and lower in $\mathrm{MgO}$ and $\mathrm{FeO}^{*}$ than average Hawaiian mugearite (column 18, Table 3). 


\section{TOW 6-123-D Alkalic Basalt}

A large proportion of the dredge haul consists of highly altered basalts and only a small amount of less-altered material was found for analysis. Unfortunately, no thin section of this less-altered material has been made. The rock is light gray in color, pitted with rusty iron hydroxides after altered olivine, which forms perhaps $10 \%$ of the rock. The groundmass is about 50\% feldspar, the remainder divided between tiny grains of clear clinopyroxene and cubes and octahedra of titanomagnetite, with lesser olivine altered to iddingsite. A wide range of feldspar compositions were found, with labradorite predominant among the scattered microphenocrysts of feldspar, and andesine and oligoclase forming slender laths in the groundmass. Potash oligoclase is particularly abundant. The sample analyzed, 123-15 (column 2, Table 3), is both lower in $\mathrm{SiO}_{2}$ and higher in $\mathrm{K}_{2} \mathrm{O}$ than average Hawaiian alkalic olivine basalt (column 15). It is unusually high in $\mathrm{TiO}_{2}$, possibly suggesting a deeper source than Hawaiian alkalic basalt (Hubbard, 1969).

\section{TOW 6-128-D Mugearite and Sodic Hawaiite (Plate 5, Figures 1, 2)}

This dredge haul was at the base of a sediment cap on a westnorthwest-trending twin guyot east of the main Line Islands ridges in the Line Islands cross-trend.

The rocks dredged include tan, fine-grained, trachytic textured rocks with andesine phenocrysts $\left(\mathrm{An}_{42}\right)$ up to $3 \mathrm{~mm}$ set in a groundmass of slender laths of oligoclase $\left(\mathrm{An}_{30}\right)$ and potash oligoclase, with rare, clear clinopyroxene $\left(2 \mathrm{~V}^{+}=30^{\circ}\right)$. The mineralogy indicates that the rock is a mugearite in composition. The tan color reflects abundant clays after intersertal glass in the groundmass rendering the rock too altered for analysis.

The analyzed rock (128-1, Table 3) is mottled gray-green in appearance with abundant microlites of andesine and opaques (probably titanomagnetite) set in a dusky devitrified glass. Occasional grains of iddingsite after olivine are present. Fresher portions of the rock have an almost pink appearance. The dark color of the more altered portions may be due to alteration of the olivines and to some extent the opaques, which are rimmed with red iron oxides in reflected light. The rather low total of the analysis reflects the incorporation of water into the altered olivines and into the glass. The rock is rather low in alkalis and incompatible trace elements $(\mathrm{Sr}, \mathrm{Rb}, \mathrm{Pb}$, and $\mathrm{Ba}$ ) in spite of its felsic composition. It is also rather high in $\mathrm{SiO}_{2}$. It is comparable in certain respects to hawaiites of the Hawaiian and Samoan islands, but apparently belongs to a mildly alkalic or perhaps even transitional lineage. It is a strong departure from the potassic nephelinites dredge elsewhere on the Line Islands cross-trend and demonstrates the diversity of that set of ridges.

\section{TOW 6-130-D Alkalic Basalt (olivine-poor basanitoid) (Plate 3, Figures 7, 8)}

This dredge station is across the top of a guyot that may have supplied volcanogenic sediments drilled nearby at DSDP Site 165 . The lavas are aquagene tuffs, possibly erupted after erosional leveling of this guyot.

The rock analyzed (130-2, Table 3) is dark gray, fine grained, and has about $15 \%$ microphenocrysts of pale brown titanaugite, lesser olivine (Fовь) partly altered to clays and iron hydroxides, and rare labradorite up to $2 \mathrm{~mm}$ in size. The groundmass is about $40 \%$ plagioclase (Ans4 on the average, in lath-shaped grains) and lesser potash oligoclase. The remainder is pale brown titanaugite, olivine $\left(\mathrm{FO}_{7}\right)$, and opaques. The groundmass olivine and potash oligoclase qualify this rock as an alkalic basalt, but the olivine is too scarce for the rock to be termed an alkalic olivine basalt in the classification of Macdonald and Katsura (1964). Chemically, the rock is low in $\mathrm{SiO}_{2}$ and high in $\mathrm{Sr}, \mathrm{Rb}, \mathrm{Ba}$, and $\mathrm{Pb}$. Tio 2 is exceptionally high. The rock falls in the field of Samoan posterosional basanites and nephelinites on an alkali-silica diagram (Figure 3) although it is lower in $\mathrm{MgO}$ than those lavas (Hawkins and Natland, 1975). The optional name basanitoid possibly applies. The low $\mathrm{SiO}_{2}$ and high incompatible trace element contents would put this rock at the mafic end of a strongly alkalic lineage. The "mugearites" cored nearby at DSDP Site 165 are also strongly alkalic, and could have differentiated from a basanitic or nephelinitic parent perhaps similar to 130-2.

Sand grains among the hyaloclastites of this dredge haul include grains of sanidine, hortonolitic olivine $\left(2 \mathrm{~V}^{-}=60^{\circ}\right)$, fibrous brown amphibole, and cumulate olivine-augite slumps. Rock types represented among sand grains include basalt and biotite-bearing benmoreite (predominantly potash oligoclase). These sand grains suggest that a full range of alkalic differentiated rocks are present at the summit of this seamount.

\section{TOW 6 133-D (Plate 4, Figures 1, 2}

A wide range of rock types were dredged from this seamount. Four of these were analyzed. Several others described were not.

A fine-grained olivine-poor rock was analyzed (133-21; Plate 4, Figure 4) and proved to be a tholeiitic basalt. The rock is largely glassy, with tiny crystallites of sheaf-like pyroxenes and plagioclase, typical of quickly quenched submarine eruptives. The glass is dusky brown in color and riddled with incipient crystallites with an opaque appearance, but which probably are also pyroxenes and feldspars. The total of the analysis indicates that the rock is fresh, and there is no doubt about its tholeiitic chemistry. It falls in the tholeiitic field of Hawaiian basalts on the alkali-silica diagram (Figure 3 ) and has hypersthene in the reduced norm. $\mathrm{TiO}_{2}$ is low and $\mathrm{K} / \mathrm{Rb}$ is high. The rock is comparable to olivine-poor Hawaiian tholeiites in every respect but one. $\mathrm{Cu}$ is too low. Few Hawaiian tholeiites have copper below 90 ppm (Herlicksa, 1967).

A picritic alkalic olivine basalt was found in this dredge haul, but the rock was not analyzed. It is dark gray with about $40 \%$ phenocrysts of olivine altered to clays and iron hydroxides (about $0.5 \mathrm{~cm}$ in size) and lesser augite phenocrysts up to $1 \mathrm{~cm}$. The groundmass contains andesine $\left(\mathrm{An}_{\mathrm{As}}\right)$, potash oligoclase, titanaugite, minor olivine altered to iddingsite, and abundant magnetite. It is probably an alkalic olivine basalt of the picritic type common on the Hawaiian Islands (Macdonald and Katsura, 1964). Ozima and Saito (1974) give an ${ }^{40} \mathrm{Ar} /{ }^{39} \mathrm{Ar}$ age of $84.4 \pm 0.9$ m.y. B.P. for this rock.

Three rocks were analyzed which fall into the alkalic andesite category of island and seamount lavas. In certain respects they are comparable to hawaiites, although the fractionation trend that can be to clays and iron hydroxides or iddingsite. Opaques are very abundant, chiefly titanomagnetite. One rock is so rich in magnetic minerals that a thin-section chip weighing over $20 \mathrm{~g}$ can be lifted with a hand magnet. The feldspars range from sodic labradorite in composition, primarily among the rather abundant phenocrysts, to andesine and oligoclase in the groundmass, and abundant potash oligoclase, most abundant in the most alkalic of the rocks. Lesser clear subcalcic augite $\left(2 \mathrm{~V}+=30^{\circ}\right)$ is also present. The three rocks analyzed increase in $\mathrm{SiO}_{2}$, $\mathrm{K}_{2} \mathrm{O}$, total alkalis (recalculated to $100 \%$ ), and $\mathrm{Rb}$ in the sequence 133 9, 133-23, 133-22 (Plate 4, Figure 3). Sample 133-9 has unusually high $\mathrm{Ba}, \mathrm{Ni}, \mathrm{Cu}$, and $\mathrm{Zn}$, suggesting that it is rich in sulfides or possibly barium sulfate, perhaps marine in origin. Both 133-9 and 133-23 are somewhat altered, and such contamination is plausible, although it was undetected in thin section. A possible fractionation sequence for these lavas is indicated in Figure 3. There is an essentially vertical crossing of the boundary between tholeiitic and alkalic series lavas exhibited by the three lavas, plus what is the probable position of a more olivine-rich tholeiitic basaltic precursor to 133-21. This type of transition to more alkalic compositions occurs on Tutuila and Upolu in the Samoan Islands (Natland, 1975) and also is found in lavas of the Molokai Pali, Hawaii (Beeson, 1973). It is possible that deep-seated fractionation of aluminous clinopyroxene is responsible for this type of transition, as suggested by Beeson.

Sand grains of interlocking anorthoclase and/or sanidine crystals are also found in phosphatized limestone-cemented sandstones in dredge 133. Isolated sanidine and ferrosalite grains of phenocryst size are also present. This seamount has developed a full series of differentiated lavas, and of all the seamounts dredged in the Line Islands chain has the widest variety of rock types dredged. A history comparable to Hawaiian shield volcanoes is indicated, with progressive development of more alkalic basalts, then differentiation at shallow levels to produce trachytes. "Post-erosional" lavas (basanites and nephelinites), however, were not dredged from this seamount.

\section{TOW 6-137-D Phonolite (Plate 4, Figures 3, 4)}

Pale yellow to pale bluish-green, angular to subrounded, platy phonolites were obtained in this dredge haul from a north-northwesttrending seamount in the northern portion of the Line Islands chain (Winterer, this volume, fig. 1). Some of the rocks are set in an altered clay and zeolite-rich, fine-grained, light green breccia matrix, previously described as a possible submarine ignimbrite. Most clasts are cemented in phosphatized foraminiferal limestone. The green clasts are fresher than the yellow ones and contain limpid euhedral phenocrysts of sanidine and nepheline. Aegerine augite, pleochroic green to yellow, is abundant as microphenocrysts and groundmass microlites. Small crystals of isotropic haüyne, with abundant dust inclusions, are also present. Sanidinemicrolites, identified by X-ray powder diffraction patterns, are the bulk of the groundmass. Analcime is present in the groundmass as well. The analyses of two of the fresher clasts are high in total alkalis and low in $\mathrm{SiO}_{2}$, leading to considerable nepheline 
in the norm. The totals of the analyses are consistent with $5 \%$ or more $\mathrm{H}_{2} \mathrm{O}^{+}$in the groundmass analcime and zeolites. In the analyzed specimens, these appear to be primary minerals. The positions of the lavas on the alkalis-silica diagram (Figure 3) suggest a strongly alkalic lineage, with a probable basanite or nephelinite parent. A palagonitized hyaloclastite with abundant titanaugite phenocrysts and no plagioclase was obtained in the same dredge haul and could be an altered basanite.

\section{TOW 6 142-D Trachyte}

The rocks dredged from this seamount are dark green, fine grained, and sparsely porphyritic, mottled with purple and brown. They are angular manganese oxide-crusted fragments, probably dredged from a flow. The mottled patches are actually separate rock fragments, often more vesicular and/or more flow textured than the encircling rock. In thin section, the rocks have about $5 \%$ sanidine phenocrysts up to $3 \mathrm{~mm}$ and rare aegerine augite phenocrysts set in a groundmass of sanidine microlites and abundant hematite. The analysis, 142-1, reveals the rock to be moderately alkalic for the amount of $\mathrm{SiO}_{2}$ present. It falls along the trend of strongest silica enrichment among Samoan volcanoes. It may have had an alkalic olivine basalt parent which differentiated chiefly olivine as the major mafic mineral (Macdonald, 1968), or it may have had a basaltic parent closer to tholeiitic basalt in composition. The single analysis cannot fix the fractionation trend sufficiently to specify the parent more precisely.

The trachyte from dredge 142 has been determined to be $128 \pm 5$ m.y. old by ${ }^{40} \mathrm{Ar} /{ }^{39} \mathrm{Ar}$ incremental heating techniques (Ozima and Saito, 1974). This is up to 20 m.y. older than the ages of basement determined at DSDP sites within the Line Islands cross-trend, and up to $40 \mathrm{~m} . \mathrm{y}$. older than the youngest ages determined within the crosstrend. The north-northwest-trending northern Line Islands ridges are thus an older belt of topography than the cross-trend.

\section{Horizon Guyot (Plate 4, Figure 5)}

Horizon Guyot is a very large, sediment-capped, flat-topped ridge at the northern terminus of the Line Islands. It trends approximately east-northeast and is thus nearly perpendicular to the northernmost Line Islands ridges. The ridge from which the trachyte of dredge 142 was obtained trends directly toward Horizon Guyot, intersecting it at about the location of a saddle separating the two summit platforms of the guyot (see Figure 1). The summit has been dredged four times (Hamilton, 1956; Lonsdale et al., 1972) and cored by DSDP twice (Winterer, Ewing, et al., 1973) with Site 171 recovering shallow-water fossils, erosional debris, and plant remains in addition to penetrating several basalt flows. Natland (in Heezen et al., 1973) described several basalts from the dredge hauls of Horizon Guyot and determined that tholeiitic basalts are probably abundant at its summit. Analyses of basalts from Site 171 given by Bass et al. (1973) are also tholeiitic. These basalts were drilled 125 meters above basement which was estimated to be possibly as old as 120 m.y. based on sedimentation rates extrapolated from the last well-dated (Cenomanian) horizon in the core. This is essentially the same age as the northern Line Islands ridges at dredge station 142 . Volcanism may have lasted until 100 m.y. on Horizon Guyot, however (Winterer, Ewing, et al., 1973).

A previously undescribed basalt from Horizon Guyot has been analyzed and is listed in Table 3 (MP-25-2F-2; Plate 4, Figure 5). Dredged from the southern edge of the western summit on MID-PAC Expedition (Hamilton, 1956), the rock is an alkalic olivine basalt. Olivine has been altered to clays and iron hydroxides form moderately abundant phenocrysts in the basalt, although brown titanaugite tinted with shades of pink is a somewhat more abundant phenocryst, forming up to $15 \%$ of the rock. Scattered phenocrysts of brown amphibole up to $0.5 \mathrm{~cm}$ in size are also present and have ravelled edges riddled with tiny grains of magnetite where they have reacted with the surround melt. The groundmass is predominantly plagioclase and titanaugite, with lesser olivine altered to iddingsite or clays, and opaques. Glass altered to clays forms no more than $10 \%$ of the groundmass. The plagioclase is predominantly labradorite but probably ranges in composition to potash oligoclase, also present in the groundmass. The latter is typically riddled with apatite needles and has irregular extinction. Groundmass zones around the amphibole phenocrysts some- times have tiny amphibole grains, either left from the reaction rim around the phenocrysts or locally stabilized by the presence of the phenocrysts and crystallized directly from the melt.

The total of the analysis is consistent with the moderate degree of alteration seen in thin section. The rock is surprisingly potassic, probably related to the abundance of amphibole phenocrysts. $\mathrm{Ba}$ and $\mathrm{Rb}$ are both quite high. In Chapter 27 it is argued that Horizon Guyot formed very close to, if not directly along, a portion of a Cretaceous spreading center in this part of the Pacific. The argument is supported by the abundance of olivine-plagioclase tholeiitic basalts dredged and cored from the summit of Horizon Guyot. These are comparable to tholeiitic basalts of the Galápagos Islands and Iceland (McBirney and Williams, 1968). The new analysis of an alkalic basalt from the summit of one of the two platforms of the guyot demonstrates that Horizon Guyot is composite and has had a more complex petrologic evolution than previously known. Alkalic basalts are known to form cappings on the older islands of the Galápagos (McBirney and Williams, 1968); possibly the present rock is comparable to those.

\section{Necker Ridge 7 TOW 6-144-D Alkalic Gabbro (theralite) (Plate 4, Figure 6)}

Alkalic basalts and gabbros were obtained in this dredge haul across the summit part of Necker Ridge. Fossils possibly as old as Late Cretaceous were also obtained (Natland, in Heezen et al., 1973). An analysis of the gabbro is given here (144-2, Table 3). The gabbro has about $20 \%$ olivine phenocrysts altered to clays stained with iron hydroxides, plus abundant purplish titanaugite laths interlocked with labradorite and andesine $\left(\mathrm{An}_{37}\right)$. Feldspar composition is not homogeneous throughout the thin section. Potash oligoclase riddled with apatite needles forms patches with irregular extinction and lower relief between plagioclase and clinopyroxene grains. The pyroxene has a low positive optic angle of $30^{\circ}$ or less, variable with zoning, lower near the edges of the grains. These low optic angles are characteristic inferred for these lavas crosses from mildly alkalic to strongly alkalic compositions. All the lavas are felsic, and carry 5\%-10\% olivine altered of titanaugite (Macdonald, 1968). Some of the titanaugites are rimmed with green aegerine augite, a further indication of alkalic chemistry. Opaques are abundant, and both titanomagnetite and ilmenite are present. Alteration is confined to the olivines and to clays lining irregular cavities between mineral grains.

The analysis of this rock shows it to be somewhat more alkalic than average Hawaiian alkalic olivine basalt (Table 3), but with much higher $\mathrm{TiO}_{2}$. Sr, Ba, Rb, and $\mathrm{Zr}$ are high, consistent with the alkalic chemistry. A minimum age of 61.3 m.y. has been obtained on this rock (K. Ozima, personal communication) proving that volcanism along Necker Ridge ended long before Hawaiian volcanism at Necker Island (9-11 m.y.; McDougall, 1964; Jackson et al., 1972). The alkalic rocks are more typical of island or seamount volcanism than fracture zone volcanism which usually is tholeiitic. The rocks therefore weigh against a fracture zone origin for Necker Ridge, although they do not eliminate it altogether.

\section{Wake Guyots Aries 5-19 Trachyte (Plate 4, Figures 7, 8)}

One of the freshest rocks obtained on SIO's Expedition Aries Leg 5 is a trachyte from Wilde Guyot. Its analysis is given in Table 3 (A-519-1). It contrasts to the potassic absarokite dredge from Scripps Guyot on the same expedition (analysis A-5-25-1, Table 2), demonstrating that the Wake Guyots are quite heterogeneous petrologically. The rock is trachytic in texture, with a few microphenocrysts of anorthoclase set in a groundmass of $90 \%$ sanidine microlites, and between $2 \%$ and $3 \%$ each tiny crystals of clinopyroxene and magnetite. On an alkali-silica diagram (Figure 3), the rock falls well within the alkalic field. Comparison with Samoan lineages suggests that this trachyte probably had an alkalic basalt parent and belongs to a moderately alkalic lineage. The $\mathrm{Ba}$ and $\mathrm{Sr}$ contents suggest that more silicic trachytes are present on Wilde Guyot. This is because crystal fractionation first of sodic plagioclase and then of anorthoclase (with possible apatite) strips first $\mathrm{Ca}$, then $\mathrm{Sr}$, and finally $\mathrm{Ba}$ from trachytic residual. $\mathrm{Ba}$ in this trachyte, however, is not depleted, suggesting that this rock does not represent the extreme of fractionation in its lineage. 


\section{PLATE 1}

Potassic Nephelinites and Associated Xenoliths from the Line Islands Chain

Figure 17 TOW 6-122-1. Potassic nephelinite, plane light. Microphenocrysts of titanaugite set in a partially altered vitrophyric groundmass. The trelliced chains of opaques are typical of lavas quickly quenched under water. The large dark patch to the right is a zone of highly concentrated $\mathrm{Fe}-\mathrm{Ti}$ oxides near a large vesicle.

Figure 27 TOW 6-129-2. Potassic nephelinite, plane light. Large clinopyroxene to left, zoned from pale green diopidic augite to an outer rim of pinkish-brown titanaugite. A reddish-brown amphibole phenocryst enclosing a grain of titanaugite is off to the left.

Figure 37 TOW 6-129-2. Clinopyroxene-amphibole-olivine xenolith, plane light. Olivine is altered to clays and opaques. The pyroxene is fresh, and pale green. The amphibole is pleochroic from dull brown to green and appears to form between more idiomorphic pyroxenes.

Figure $4 \quad 7$ TOW 6-129-2. Large amphibole megacryst in plane light with abundant exsolved opaques and enclosing large grains of apatite. An altered olivine phenocryst is on the left border of the picture. The amphibole is a darker and duller brown than the reddish-brown phenocrysts (Figure 2). The exsolved opaques indicate that it is not stable at the same pressures as the phenocrysts. It may have crystallized from the melt at higher pressure or be a xenocryst.

Figure $5 \quad 7$ TOW 6-134-1. Potassic nephelinite. Abundant titanaugite and biotite phenocrysts set in a somewhat altered glassy groundmass charged with opaques and perovskite. The large rounded grain to the left is a completely opaque mica, rimmed with brown mica.

Figure $6 \quad 7$ TOW 6-134-1. Olivine-clinopyroxene-biotite clump in potassic nephelinite in plane light. Olivine is highly altered to clays and reddish iron hydroxides (lower left). Biotite is pleochroic, varying from brown (near-horizontal crystals through center of photo) to clear (lower center showing cleavage). The clinopyroxene is zoned from pale green diopsidic augite to brown titanaugite (upper left and lower right).

Figure 7 TOW 6-134-1. Potassic nephelinite in plane light. Biotite, titanaugite, and $\mathrm{Fe}-\mathrm{Ti}$ oxides set in brown glass with phillipsite-lined vesicle to right.

Figure 87 TOW 6-138-1. Groundmass of potassic nephelinite, plane light. Titanaugite and $\mathrm{Fe}$ - $\mathrm{Ti}$ oxides (opaques) set in brown slightly vesicular glass. Note absence of feldspar. 
PLATE 1
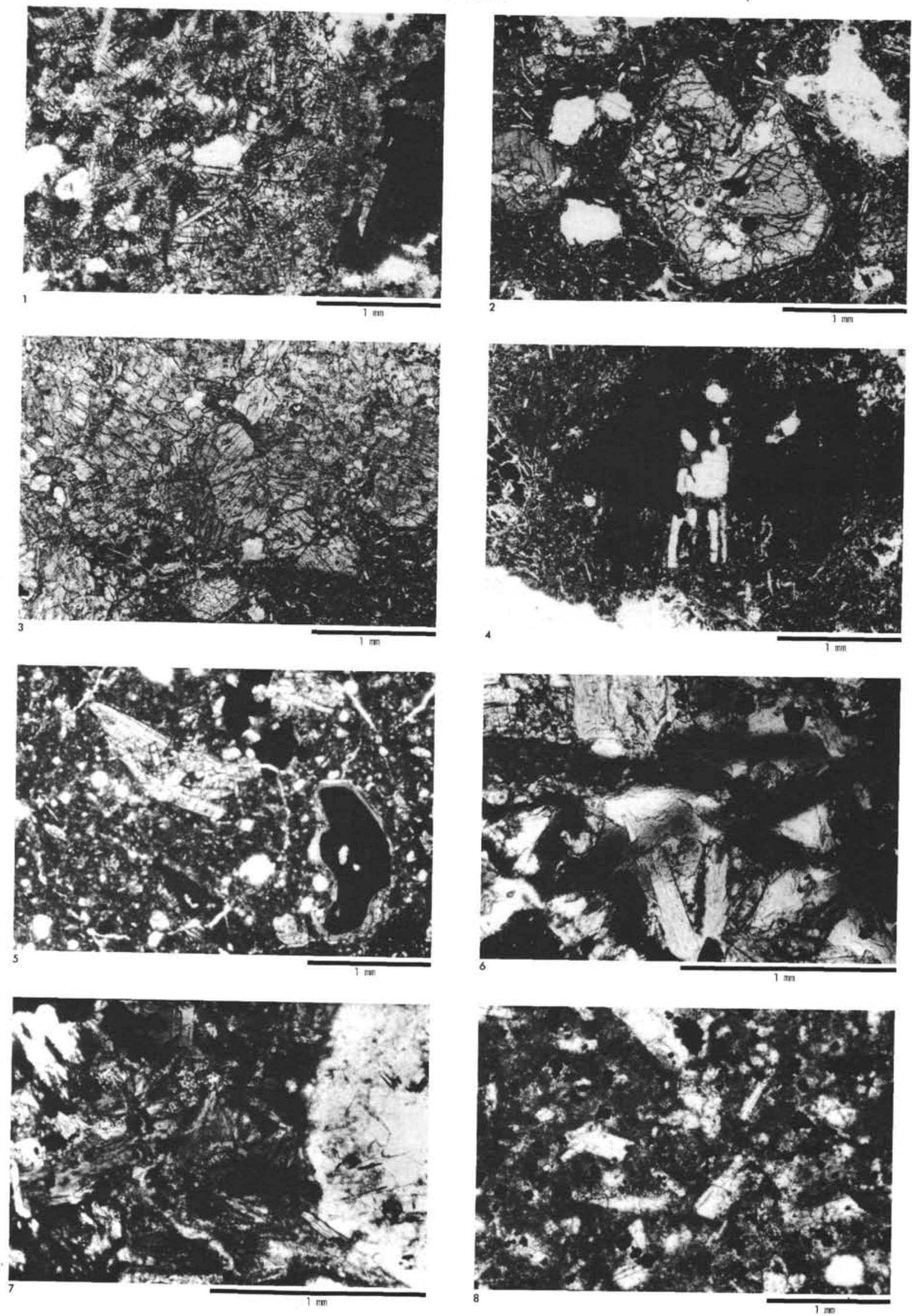


\section{PLATE 2}

Xenoliths and Pegmatoids of Dredge 7 TOW 6-134-D

Figure 17 TOW 6-134-1. Biotite-clinopyroxene xenolith in potassic nephelinite, crossed nicols. The clinopyroxene is pale green and has abundant exsolution cavities sometimes filled with biotite or ilmenite. One clinopyroxene grain, however, located just left of center, is unaltered. The biotite laced throughout the clinopyroxene has uniform extinction. A phillipsite-lined vesicle is at lower right.

Figure 27 TOW 6-134-1. Biotite-clinopyroxene xenolith, crossed nicols, showing both unaltered clinopyroxenes (left center) and exsolved clinopyroxenes, well-formed biotite crystals, and one altered olivine grain (dark patch) upper center.

Figure 37 TOW 6-134-1. Another clinopyroxene-biotite xenolith, crossed nicols. A network of irregularly oriented clinopyroxene grains with extremely irregular outline, all with marked exsolved opaques, intergrown with biotite having uniform extinction. This is interpreted to mean the biotite crystallized after the clinopyroxene.

Figure $4 \quad 7$ TOW 6-134-1. Same as Figure 3, only in plane light.

Figure $5 \quad 7$ TOW 6-134-N. Pegmatoidal segregation in 1341 , potassic nephelinite, crossed nicols. Crystals of titanaugite, biotite, and apatite set in brown glass.

Figure 67 TOW 6-134-N. Same as Figure 5, only in plane light.

Figure $7 \quad 7$ TOW 6-134-1. Leucite syenite xenolith, in potassic nephelinite, crossed nicols. Interlocking grains of sanidine, biotite, and leucite (isotropic) are shown.

Figure $8 \quad 7$ TOW 6-134-1. Same as Figure 7, only in plane light. 
PLATE 2
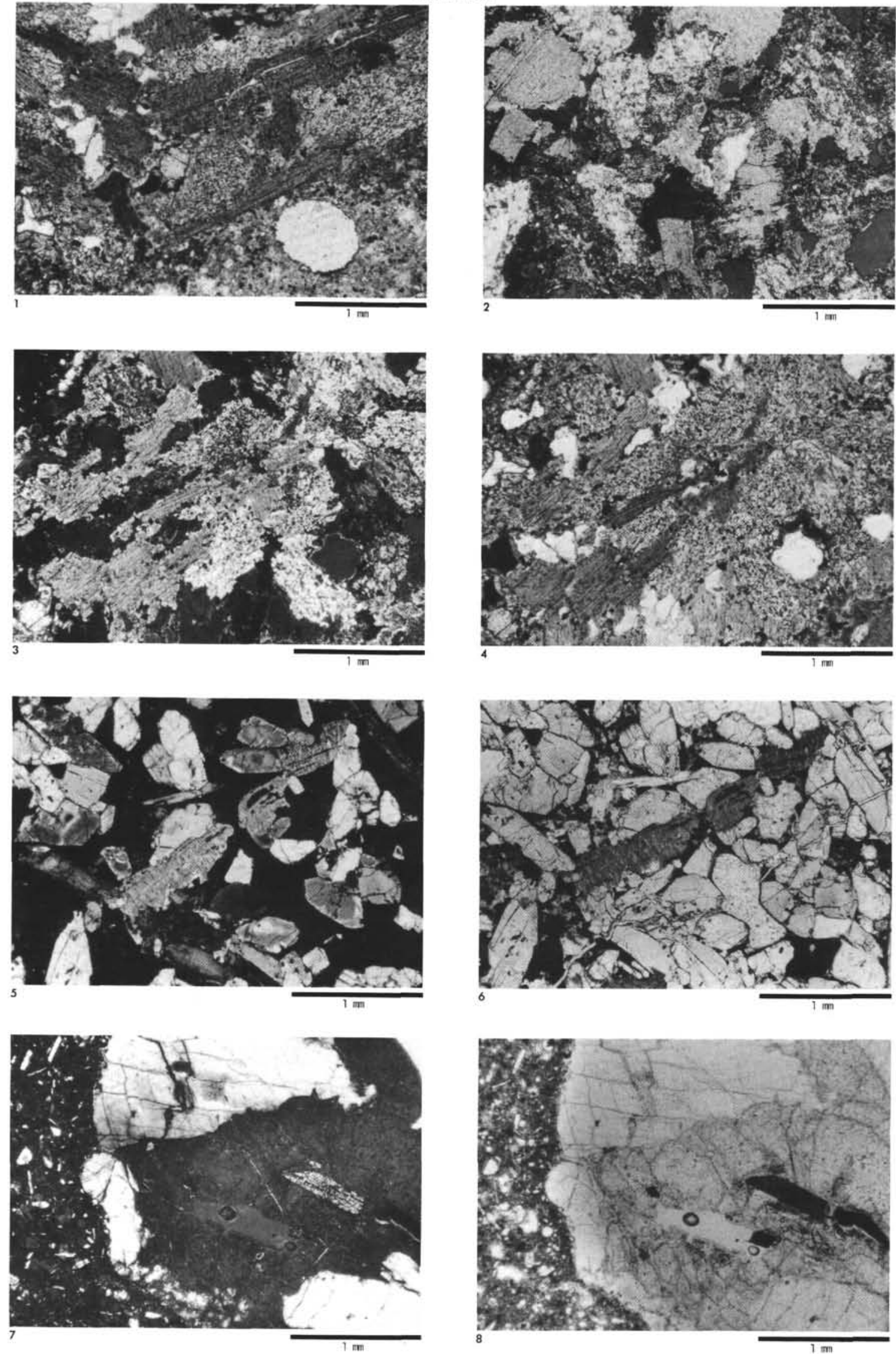


\section{PLATE 3}

Potassic Nephelinites of the Line Islands Chain

Figure 17 TOW 6-134-1. Biotite clinopyroxene xenolith showing a rimming of biotite toward the outer (right) margin of the xenolith. This is a further suggestion that the biotite is secondary, caused by infiltration of a clinopyroxene matrix by volatilerich undersaturated magmas and/or fluids.

Figure 27 TOW 6-138-1. Strongly zoned clinopyroxene phenocryst in potassic nephelinite. The center of the crystal is bright green diopsidic(?) augite ( 2 $\left.\mathrm{V}^{+} \sim 60^{\circ}\right)$. The rim is brownish titanaugite. Plane light.

Figure 37 TOW 6-138-1. Amphibole xenocryst in potassic nephelinite reacting with surrounding melt to form $\mathrm{Fe}-\mathrm{Ti}$ oxides and a thin rim of brown mica (biotite?), plane light.

Figure 4 Aries 5-25. Zoned amphibole phenocryst crosssection and titanaugite phenocrysts in potassic nephelinite from the Wake Guyots. The groundmass is predominantly titanaugite with minor feldspar, Fe-Ti oxides, and dusty brown glass. Plane light.

Figure 5 Aries 5-25. A zoned clinopyroxene phenocryst in potassic nephelinite. The crystal's interior is pale green diopsidic augite, the rim titanaugite. An amphibole phenocryst is off to the right.

Other Lavas from the Line Islands Chain

Figure 67 TOW 6-119-2. Mugearite, crossed nicols, showing abundant oriented twinned crystals and microlites of oligoclase and scattered opaques.

Figure $7 \quad 7$ TOW 6-130-2. Alkalic olivine basalt (or basanite), crossed nicols. The large crystal at left is a partially resorbed olivine megacryst. The smaller grains to the right are olivines and clinopyroxenes. Plagioclase is relatively abundant in the groundmass.

Figure $8 \quad 7$ TOW 6-130-2. Large, twinned clinopyroxene phenocrysts in alkalic olivine basalt, crossed nicols. 
PLATE 3
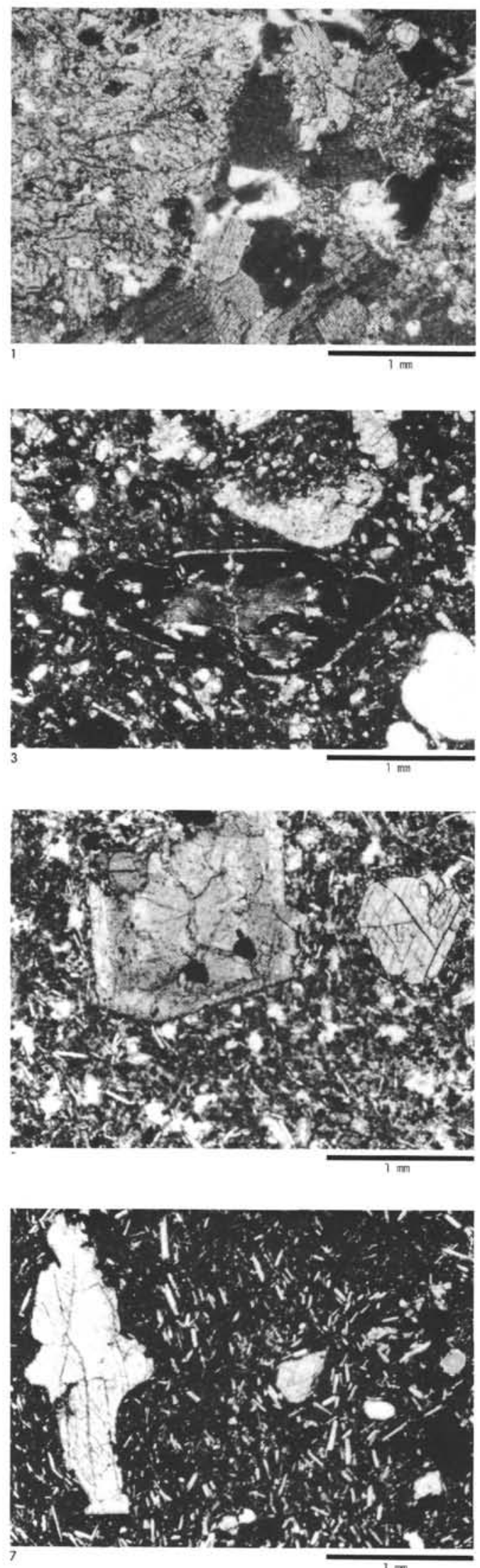
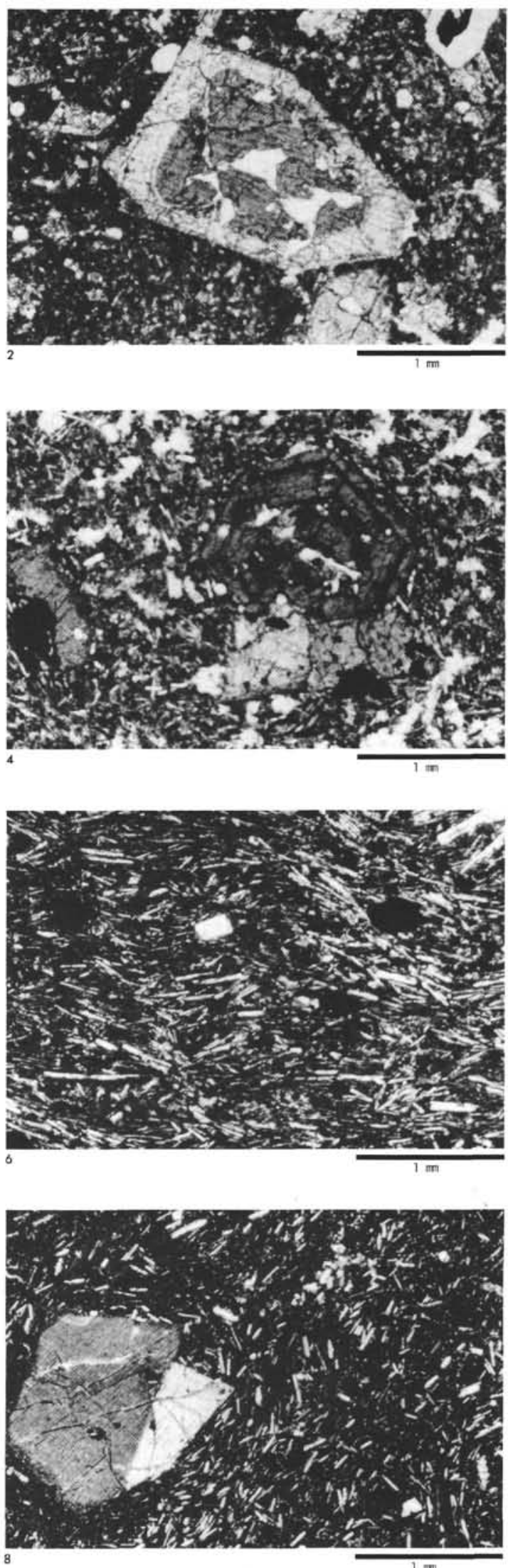


\section{PLATE 4}

Other Lavas from the Line Islands Chain Continued)

Figure 17 TOW 6-133-21. Twinned plagioclase and clinopyroxene in tholeiitic basalt, crossed nicols.

Figure 27 TOW 6-133-22. Large Carlsbad-Albite twinned andesine phenocryst showing multiple zones in hawaiite, crossed nicols.

Figure 37 TOW 6-137-1. Large green amphibole phenocryst in phonolite, plane light. The two large clear feldspar crystals are sanidine.

Figure $4 \quad 7$ TOW 6-137-1. Nepheline crystal in trachyte, crossed nicols.

Figure $5 \quad$ MP-25-2F-2. Alkalic olivine basalt from Horizon Guyot, plane light. The dark gray crystal reacting with the surroundings to form opaques is amphibole. The other phenocrysts are titanaugite, and olivine (not shown).

Figure $6 \quad 7$ TOW 6-144-D. Fine-grained gabbroic rock from Necker Ridge, crossed nicols. Pinkish-brown titanaugite and plagioclase predominate. Most intergranular material is altered to layered clays (upper center). Olivine is sparse and completely altered to clays and Fe-hydroxides (near right margin).

Figure 7 Aries 5-19. Trachyte, plane light. A zoned and partially resorbed oligoclase phenocryst is set in a groundmass of potash oligoclase, anorthosite, magnetite and minor clinopyroxene.

Figure $8 \quad$ Aries $5-19$. The same as Plate 4, Figure 7, only with crossed nicols. 
PLATE 4
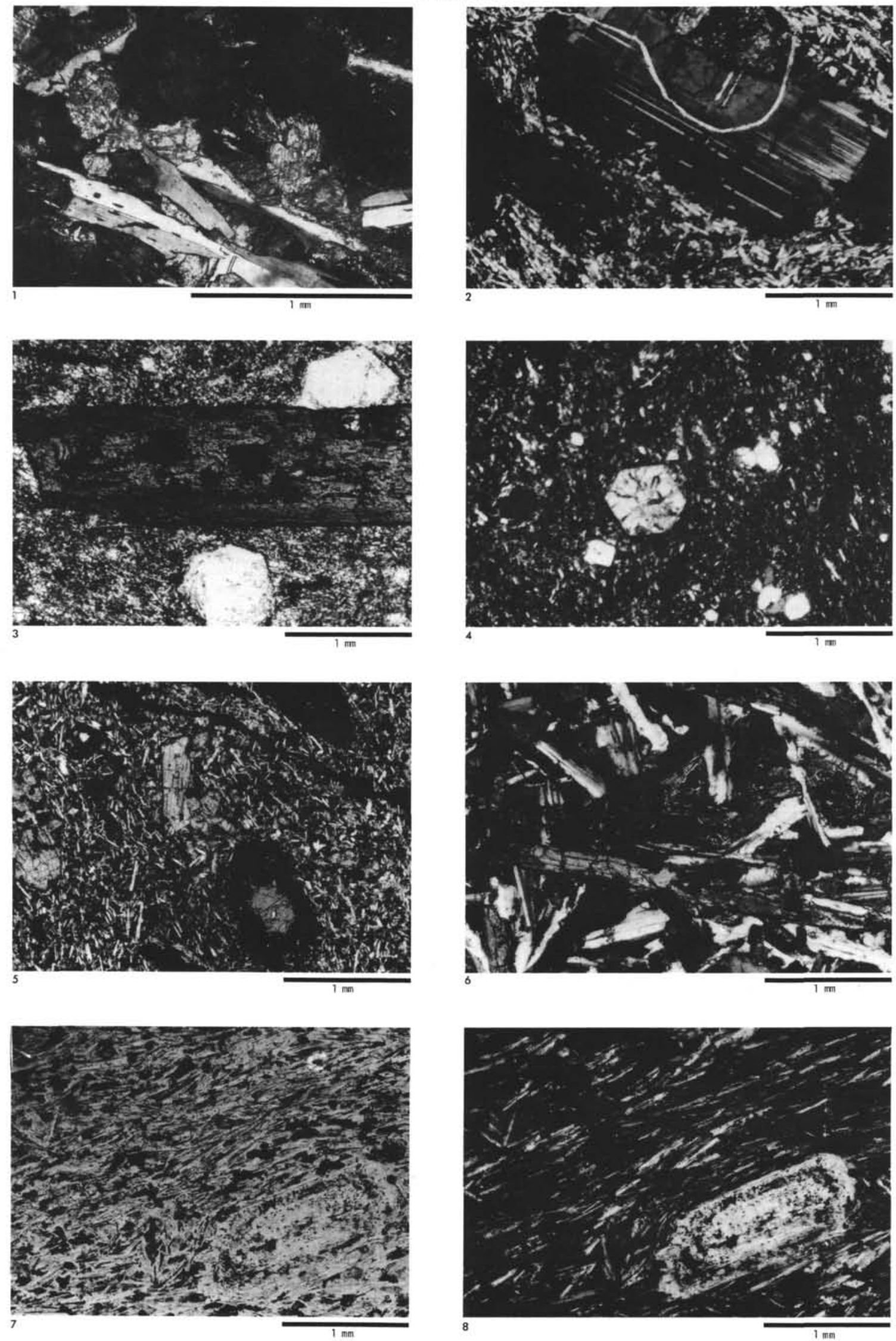
PLATE 5

Pillow Breccias and Hyaloclastites Dredged on 7 TOW Leg 6

Figure 17 TOW 6-128-D. Jointed pillow rind crusted with breccia.

Figure 27 TOW 6-128-D. Variety of volcanic rocks dredged. At left is a jointed pillow fragment, partially crusted with hyaloclastite breccia. At lower right are two sawed pieces of hyaloclastite showing poorly sorted angular fragments. At upper right is a flow laminated volcanic slab, broken along joints defined by the orientation of plagioclase crystals in the rock. The rock type throughout is hawaiite, and all pieces are intensely altered to clays and zeolites. The colors are buff, yellow, brown, and grayish-green.

Figure $3 \quad 7$ TOW 6-129-D. Composite boulder of reddishorange palagonitic hyaloclastite, interlayered cream-colored phosphorite replacing planktonic foram-nanno ooze, unaltered foram-nanno ooze, and a thick carapace of ferromanganese oxides.

Figure $4 \quad 7$ TOW 6-129-D. Hyaloclastite breccia boulders, one with ferromanganese oxide crust broken away, the other as it arrived on deck, completely encased in black ferromanganese oxides.

Figure 57 TOW 6-129-D. Hyaloclastite-phosphorite mixed boulders. The boulder at left has hyaloclastite breccia cemented by cream-colored hard phosphorite after foram-nanno ooze. The boulder on the right is bedded, with phosphorite predominant in the lower half, and reddish palagonitized volcanic breccia in the upper half. Top is indicated by the thicker ferromanganese crust above the breccia layer. The cobble on the left was completely encased in ferromanganese oxides before it was broken on deck. The layered cobble was broken by the dredge. 


\section{PLATE 5}
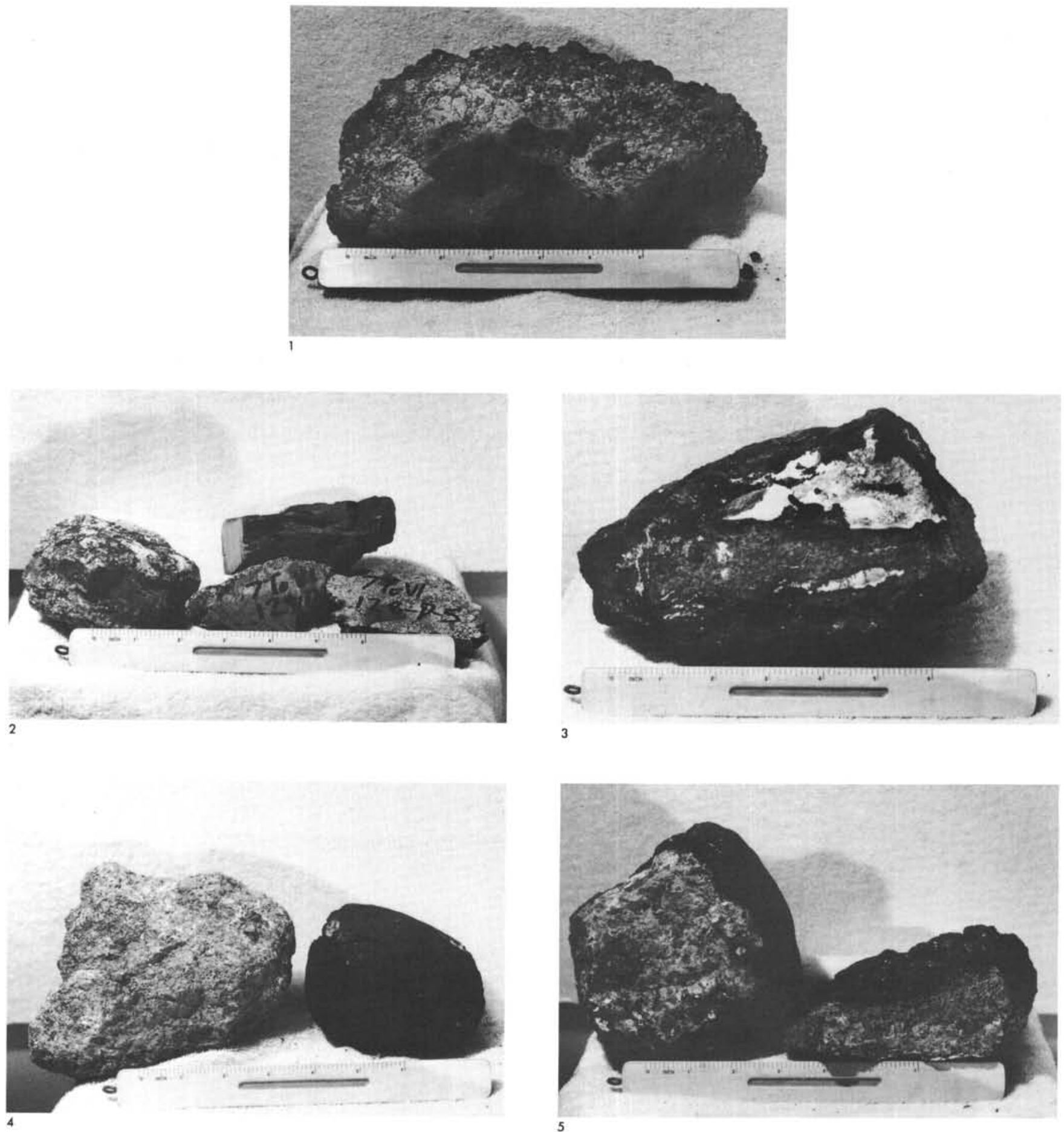